OPEN ACCESS

Edited by:

Takaomi Sanda,

National University of Singapore,

Singapore

Reviewed by:

Andrea Di Cataldo,

University of Catania, Italy Joanna Kitlinska

Georgetown University, United States

*Correspondence:

Mohammad Taher

mohammad_823@yahoo.com

Soudeh Ghafouri-Fard

s.ghafourifard@sbmu.ac.ir

Specialty section: This article was submitted to

Pediatric Oncology,

a section of the journal

Frontiers in Oncology

Received: 26 October 2020

Accepted: 11 January 2021

Published: 24 February 2021

Citation:

Rezaei O, Honarmand Tamizkar K Hajiesmaeili $M$, Taheri $M$ and

Ghafouri-Fard S (2021)

Non-Coding RNAs Participate in the Pathogenesis of Neuroblastoma.

Front. Oncol. 11:617362.

doi: 10.3389/fonc.2021.617362

\section{Non-Coding RNAs Participate in the Pathogenesis of Neuroblastoma}

\author{
Omidvar Rezaei ${ }^{1}$, Kasra Honarmand Tamizkar ${ }^{2}$, Mohammadreza Hajiesmaeili ${ }^{1}$, \\ Mohammad Taheri ${ }^{3 *}$ and Soudeh Ghafouri-Fard ${ }^{2 *}$ \\ 1 Skull Base Research Center, Loghman Hakim Hospital, Shahid Beheshti University of Medical Sciences, Tehran, Iran, \\ 2 Department of Medical Genetics, Shahid Beheshti University of Medical Sciences, Tehran, Iran, ${ }^{3}$ Urogenital Stem Cell \\ Research Center, Shahid Beheshti University of Medical Sciences, Tehran, Iran
}

Neuroblastoma is one of the utmost frequent neoplasms during the first year of life. This pediatric cancer is believed to be originated during the embryonic life from the neural crest cells. Previous studies have detected several types of chromosomal aberrations in this tumor. More recent studies have emphasized on expression profiling of neuroblastoma samples to identify the dysregulated genes in this type of cancer. Non-coding RNAs are among the mostly dysregulated genes in this type of cancer. Such dysregulation has been associated with a number of chromosomal aberrations that are frequently detected in neuroblastoma. In this study, we explain the role of non-coding transcripts in the malignant transformation in neuroblastoma and their role as biomarkers for this pediatric cancer.

Keywords: miRNA, IncRNA, neuroblastoma, expression, polymorphism

\section{INTRODUCTION}

Neuroblastoma is a neoplasm originated from the neural crest of the sympathetic part of autonomic system (1) during the embryonic life (2). This malignancy is among the most common childhood cancers particularly during the first year of life (3). Neuroblastoma has a heterogeneous course in terms of both pathobiology and clinical manifestations. Several therapeutic options such as surgical removal of the tumor, chemotherapy, radiotherapy, and bone marrow transplantation are being applied for neuroblastoma (4). Spontaneous regression might also happen in the course of neuroblastoma (5). This tumor is associated with several genetic and chromosomal abnormalities that affect its clinical course and prognosis namely MYCN amplification, loss of distal portion of chromosome (chr) $1 \mathrm{p}$ and gain of $17 \mathrm{q}(6)$. Other chromosomal abnormalities detected in neuroblastoma are loss of 11q, 3p, 4p, 9p, 14q, and gain of 1q, 7q, 2p, and 11p (7-9). In addition to these chromosomal aberrations, dysregulation of several genes including non-coding RNAs (ncRNAs) are linked with this cancer (10). These kinds of transcripts have regulatory impact on other genes, hence constructing an epigenetic layer of gene regulation. They are classified based on 
their sizes to long non-coding RNAs (lncRNAs) and microRNAs (miRNAs) with the former having more than 200 nucleotides and the latter being about 22 nucleotides (11). Based on the speculation stated by the ENCODE consortium regarding the recognition of "biochemical functions for $80 \%$ of the genome" (12), ncRNAs have attained much attention during the recent decade particularly in the field of cancer research. In the current study, we explain the role of lncRNAs and miRNAs in the evolution of neuroblastoma and their role as biomarkers for this pediatric cancer.

\section{Dysregulated miRNAs in Neuroblastoma}

Chen and Stallings have measured expression of 157 miRNAs in neuroblastoma samples. They have displayed differential pattern of 32 miRNAs between tumor with favorable prognosis and those with poor prognosis. Notably, several of these miRNAs were down-regulated in neuroblastoma samples harboring MYCN amplification, which was associated with unfavorable outcome. Cell line studies have shown the role of retinoic acid in the modulation of expression of miRNAs in a $M Y C N$-amplified cell line. Among the dysregulated miRNAs has been miR-184 which participates in the regulation of apoptosis. MYCN might exert its tumorigenic effects via modulating expression of miRNAs that participate in neural cell differentiation or apoptotic processes (13).

Among the firstly discovered tumor suppressor miRNAs in neuroblastoma was miR-34a (14), which is transcribed from a frequently deleted region in neuroblastoma i.e. 1p36.23. This
miRNA was particularly down-regulated in neuroblastoma samples with 1p deletion (14). Since miR-34a inhibits expression of the E2F3 transcription factor, its down-regulation facilitates cell cycle progression (14). Subsequent studies have also verified the tumor suppressive impact of miR-34a in the neuroblastoma cells and its inhibitory effects on the expression of BCL2 and MYCN (15, 16). miR-34a also binds with the 3' UTR of ATG5 and CD44 transcripts and decreases their expressions. Down-regulation of miR-34a in neuroblastoma cells results in the over-expression of ATG5 and CD44 $(17,18)$. CD44 is a cell surface receptor which can bind with hyaluronan and induce expression of genes that promote progression of cancer (19). ATG5 can dissociate V1V0-ATPase, increase $\mathrm{pH}$ in multivesicular bodies and enhance secretion of exosomes to facilitate cancer metastasis (20). Thus, miR-34a affects the progression of neuroblastoma through different mechanisms. Figure 1 shows some aspects of participation of miR-34a in the pathogenesis of neuroblastoma.

miR-542-5p is another tumor suppressor miRNA whose down-regulation in neuroblastoma has conferred poor clinical outcome. Notably, forced up-regulation of miR-542-5p has resulted in attenuation of neuroblastoma invasive properties and tumor growth bot in vitro and in vivo (21). Moreover, expression of miR-490-5p has been diminished in neuroblastoma tissues and cells. Forced overexpression of miR-490-5p has diminished cell proliferation migration and invasiveness, prompted G0/G1 arrest in cells and induced cell apoptosis. MYEOV has been confirmed to be the target of miR-490-5p through which miR-490-5p blocks neuroblastoma progression (22). Table 1 recapitulates the results

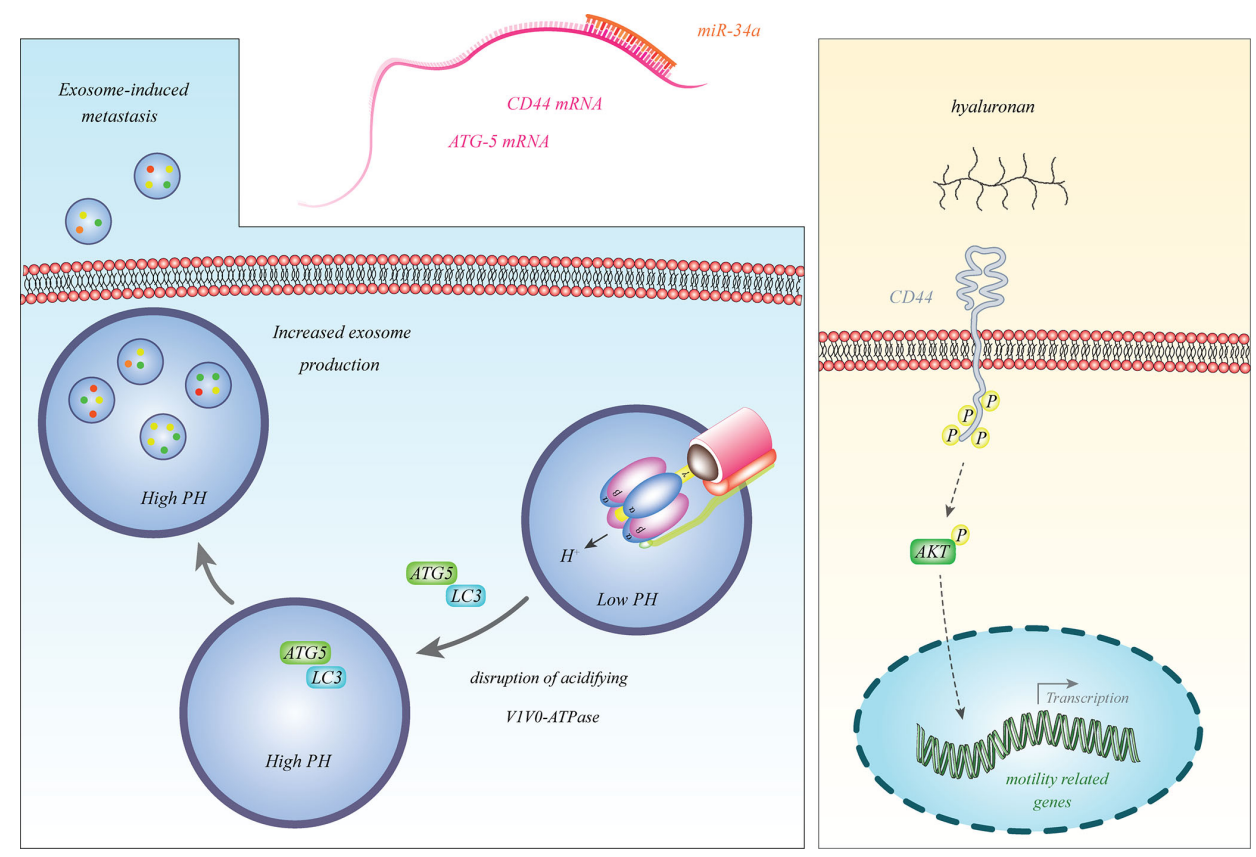

FIGURE 1 | miR-34a binds with the 3' UTR of ATG5 and CD44 transcripts to reduce their expressions. Decreased expression of miR-34a in neuroblastoma leads to over-expression of ATG5 and CD44 $(17,18)$. CD44 is a cell surface receptor which can bind with hyaluronan and induce expression of genes that promote progression of cancer (19). ATG5 can dissociate V1V0-ATPase, increase pH in multivesicular bodies and enhance secretion of exosomes to promote cancer metastasis (20). 
TABLE 1 | Down-regulated miRNA in neuroblastoma (NB, Neuroblastoma; ANT, adjacent normal tissues; OS, overall survival; EFS, event-free survival).

\begin{tabular}{|c|c|c|c|c|c|c|c|}
\hline miRNA & Specimens & Cell line & $\begin{array}{l}\text { Targets/ } \\
\text { regulators }\end{array}$ & $\begin{array}{l}\text { Signaling } \\
\text { pathway }\end{array}$ & Function & $\begin{array}{l}\text { Effect of } \\
\text { miRNA } \\
\text { down- } \\
\text { regulation } \\
\text { on patient's } \\
\text { prognosis }\end{array}$ & Reference \\
\hline $\operatorname{miR}-490-5 p$ & $\begin{array}{l}72 \text { tumor } \\
\text { tissues and } \\
\text { ANTs }\end{array}$ & $\begin{array}{l}\text { SH-SY5Y, SK-NSH, } \\
\text { U343 }\end{array}$ & MYEOV & - & $\begin{array}{l}\text { Down-regulated miR-490-5p levels correlate with } \\
\text { advanced INSS stage, lymph node involvement, } \\
\text { and poor outcome. MiR-490-5p overexpression } \\
\text { thwarts cell proliferation, migratory capacities, } \\
\text { invasive effects, and enhances the cell cycle arrest } \\
\text { and apoptosis. }\end{array}$ & $\begin{array}{l}\text { Poor } \\
\text { survival }\end{array}$ & (22) \\
\hline miR-144 & & $\begin{array}{l}\text { SH-SY5Y, SK-N-SH, } \\
\text { HUVEC }\end{array}$ & MYCN & & $\begin{array}{l}\text { miR-144 influences proliferation, apoptosis and } \\
\text { cisplatin resistance. }\end{array}$ & & \\
\hline $\operatorname{miR}-144-3 p$ & $\begin{array}{l}46 \text { pairs of NB } \\
\text { ANTs }\end{array}$ & $\begin{array}{l}\text { SK-N-SH, SH-SY5Y, } \\
\text { HUVEC, }\end{array}$ & HOXA7 & - & $\begin{array}{l}\text { miR-144-3p repression results in the advancement } \\
\text { of cell proliferation, cell cycle progression, and cell } \\
\text { migration. Down-regulation of miR-144-3p level } \\
\text { correlates with advanced tumor stage, greater } \\
\text { carcinoma size, and lymph node metastasis. }\end{array}$ & - & (23) \\
\hline \multirow[t]{3}{*}{$\operatorname{miR}-34 a$} & $\begin{array}{l}35 \text { pediatric NB } \\
\text { patients, } 15 \\
\text { normal adrenal } \\
\text { tissue }\end{array}$ & SH-SY5Y & $\begin{array}{l}\text { MMP-2, } \\
\text { MMP-14, } \\
\text { HNF } 4 \alpha\end{array}$ & - & $\begin{array}{l}\text { miR-34a down-regulation increases cell proliferation, } \\
\text { migration, and invasion. }\end{array}$ & - & (24) \\
\hline & $\begin{array}{l}18 \text { NB primary } \\
\text { and their } \\
\text { metastatic } \\
\text { tissues }\end{array}$ & SH-SY5Y, IMR-32 & CD44 & - & $\begin{array}{l}\text { miR-34a repression results in enhanced metastasis, } \\
\text { proliferation, and invasion rates in NB cells. }\end{array}$ & - & (17) \\
\hline & $\begin{array}{l}32 \mathrm{NB} \text { and } \\
\text { ANTs }\end{array}$ & $\begin{array}{l}\text { SH-SY5Y, SK-N-SH, } \\
\text { HUVEC }\end{array}$ & ATG5 & - & $\begin{array}{l}\text { proliferation, migration, and invasion rate increase } \\
\text { following the miR-34a repression, and the apoptosis } \\
\text { rate diminishes. }\end{array}$ & $\begin{array}{l}\text { Lower } \\
\text { survival rate }\end{array}$ & $(18)$ \\
\hline \multirow[t]{2}{*}{ miR-183 } & - & $\begin{array}{l}\text { IMR-32, SH-SY5Y, SK- } \\
\text { N-MC, SK-N-SH, } \\
\text { HEK293, KCLB, HEF, } \\
\text { SK-N-DZ }\end{array}$ & $\begin{array}{l}-/ \mathrm{MYCN} \\
\text { HDAC2 }\end{array}$ & - & $\begin{array}{l}\text { MYCN inhibition increases the pro-apoptotic miR- } \\
183 \text { levels. }\end{array}$ & - & $(25)$ \\
\hline & - & $\mathrm{BE}(2)-\mathrm{C}$, Kelly & $\begin{array}{l}\text { MCM } \\
\text { complex }\end{array}$ & - & miR-183 down-regulates the MCM complex. & - & $(26)$ \\
\hline miR-323a-5p & $\begin{array}{l}253 \mathrm{NB} \\
\text { patients }\end{array}$ & $\begin{array}{l}\text { SK-N-AS, SH-SY5Y, } \\
\text { IMR-32, HEK293T141, } \\
\text { CHLA-90, SK-N-BE(2), } \\
\text { LA1-5 }\end{array}$ & $\begin{array}{l}\text { CHAF1A, } \\
\text { KIF11, } \\
\text { INCENP, } \\
\text { CDC25A, } \\
\text { CCND1, } \\
\text { FADD, } \\
\text { E2F2 }\end{array}$ & - & $\begin{array}{l}\text { These miRNAs reduce cell proliferation, cell viability, } \\
\text { cell cycle, and tumor growth, though they increase } \\
\text { the apoptosis rate. }\end{array}$ & - & $(27)$ \\
\hline miR-342-5p & & & $\begin{array}{l}\text { AKT2, } \\
\text { CCND1, } \\
\text { MKNK2, } \\
\text { BCLX }\end{array}$ & & & Poor OS & \\
\hline miR-34b & - & $\begin{array}{l}\text { SH-SY5Y, IMR-32, } \\
\text { KELLY }\end{array}$ & DLL1 & $\begin{array}{l}\text { Notch- } \\
\text { Delta }\end{array}$ & $\begin{array}{l}\text { miRNA-34b markedly down-regulates the DLL1 } \\
\text { mRNA expression levels, arrests cell proliferation, } \\
\text { induces neuronal differentiation in malignant NB } \\
\text { cells. }\end{array}$ & - & (28) \\
\hline $\operatorname{miR}-145$ & - & SH-SY5Y & Bnip3 & - & $\begin{array}{l}\text { miR-145 inhibition promotes mitophagy activity and } \\
\text { subsequently increases SH-SY5Y cell survival. }\end{array}$ & - & (29) \\
\hline miR-2110 & $\begin{array}{l}\text { SEQC dataset: } \\
498 \text { NB } \\
\text { patients }\end{array}$ & $\begin{array}{l}\text { BE(2)-C, SKNDZ, CHLA- } \\
90, \text { SKNFI }\end{array}$ & TSKU & - & $\begin{array}{l}\text { miR-2110 overexpression induces cell differentiation } \\
\text { and inhibits cell survival. }\end{array}$ & $\begin{array}{l}\text { Poor OS } \\
\text { and EFS }\end{array}$ & (30) \\
\hline miR-186 & $\begin{array}{l}\text { GSE62564 } \\
\text { dataset: } 498 \\
\text { NB patients }\end{array}$ & $\begin{array}{l}\text { CHLA-136, LAN-5, } \\
\text { CHLA-255, HEK293T }\end{array}$ & $\begin{array}{l}\text { MYCN, } \\
\text { AURKA, } \\
\text { TGFBR1, } \\
\text { TGFBR2, } \\
\text { TGFß1 }\end{array}$ & TGF $\beta$ & $\begin{array}{l}\text { miR-186 lower expression levels relate to a poor } \\
\text { prognosis in NB patients that directly correlates with } \\
\text { NK activation markers. }\end{array}$ & $\begin{array}{l}\text { Poor EFS } \\
\text { and OS }\end{array}$ & (31) \\
\hline let-7 & - & KELLY, BE2C, SH-SY5Y & $\begin{array}{l}\text { TGF- } \beta \text { RI, } \\
\text { LMO1, } \\
\text { MYCN }\end{array}$ & - & $\begin{array}{l}\text { let- } 7 \text { decreases the expression levels of TGF- } \beta \text { RI, } \\
\text { LMO1, and MYCN. }\end{array}$ & - & (32) \\
\hline
\end{tabular}


TABLE 1 | Continued

\begin{tabular}{|c|c|c|c|c|c|c|c|}
\hline miRNA & Specimens & Cell line & $\begin{array}{l}\text { Targets/ } \\
\text { regulators }\end{array}$ & $\begin{array}{l}\text { Signaling } \\
\text { pathway }\end{array}$ & Function & $\begin{array}{l}\text { Effect of } \\
\text { miRNA } \\
\text { down- } \\
\text { regulation } \\
\text { on patient's } \\
\text { prognosis }\end{array}$ & Reference \\
\hline & - & $\begin{array}{l}\text { BE(2)-C, SMS-KCNR, } \\
\text { CHLA90 }\end{array}$ & $\begin{array}{l}\text {-/DFMO, } \\
\text { LIN28B, } \\
\text { MYCN }\end{array}$ & - & $\begin{array}{l}\text { Difluoromethylornithine inhibits ornithine } \\
\text { decarboxylase, which in turn regulates polyamines. } \\
\text { Polyamines regulate elF-5A, which is a modulator of } \\
\text { the LIN28/Let-7 axis. Difluoromethylornithine } \\
\text { reduces neurosphere formation, ATP production, } \\
\text { and LIN28B and MYCN protein levels yet enhances } \\
\text { let-7. }\end{array}$ & - & (33) \\
\hline & $\begin{array}{l}\text { GSE81500 } \\
\text { dataset: } 172 \\
\text { NB patients }\end{array}$ & $\begin{array}{l}\text { BE(2)C, PA-1, IMR90, } \\
\text { SK-N-AS, SH-SY5Y, } \\
\text { HEK293T, SK-N-DZ, } \\
\text { Kelly }\end{array}$ & -/MYCN & - & $\begin{array}{l}\text { Genetic loss of let- } 7 \text { is common in NB and is } \\
\text { negatively associated with MYCN amplification. } \\
\text { Down-regulation of let- } 7 \text { is associated with poor } \\
\text { outcomes. }\end{array}$ & Lower OS & (34) \\
\hline \multirow[t]{2}{*}{$\begin{array}{l}\mathrm{miR}-15 \mathrm{a} / \mathrm{miR}- \\
16-1\end{array}$} & - & $\begin{array}{l}\text { HTLA-230, HTLA-ER, } \\
\text { HCT116 TP53-/- }\end{array}$ & $\begin{array}{l}\text { BMl-1, } \\
\text { p16/p53 }\end{array}$ & - & $\begin{array}{l}\text { miR-15a/16-1 down-regulation enhances BMl-1 } \\
\text { oncoprotein up-regulation, which decreases p16 } \\
\text { tumor suppressor and increases etoposide } \\
\text { resistance. }\end{array}$ & - & (35) \\
\hline & - & $\begin{array}{l}\text { SK-N-BE(2), Shy-SY5Y, } \\
\text { MHH-NB-11, PC3, } \\
\text { RPMl-8266 }\end{array}$ & $\begin{array}{l}\text { Bcl2, } \\
\text { cyclin D1, } \\
\text { CCND1, } \\
\text { ERK } \\
\text { CXCR4 }\end{array}$ & MAPK & $\begin{array}{l}\text { Up-regulation of miR-15a/16-1, regulated by } \\
\text { CXCR4, results in the repression of BCL-2 and } \\
\text { cyclin D1. miR-15a/16-1 increases apoptosis and } \\
\text { reduces the proliferation and survival of tumor cells. }\end{array}$ & - & (36) \\
\hline $\begin{array}{l}\text { hsa-miR-34a- } \\
5 p \text {, has-let7 } \\
\text { family, hsa- } \\
\text { miR-16-5p, } \\
\text { hsa-miR-20b- } \\
\text { 5p, hsa-miR- } \\
\text { 409-3p }\end{array}$ & - & $\begin{array}{l}\text { SK-N-SH, LA-N-5, SK- } \\
\text { N-BE }\end{array}$ & -/LMO1 & - & $\begin{array}{l}\text { These miRNAs significantly diminish cell proliferation } \\
\text { of NB cell lines. }\end{array}$ & - & $(37)$ \\
\hline miR-146a & - & SK-N-SH, HEK293 & BCL11A & - & $\begin{array}{l}\text { miR-146a overexpression inhibits cell proliferation } \\
\text { and increases the apoptosis rate of human NB } \\
\text { cells. }\end{array}$ & - & (38) \\
\hline miR-129 & $\begin{array}{l}88 \mathrm{NB} \text { and } 23 \\
\text { ANTs }\end{array}$ & $\begin{array}{l}\text { NBSD, SK-N-SH, SK- } \\
\text { SY-5Y, SK-N-AS, IMR- } \\
\text { 32, Neuro-2a, BEM17, } \\
\text { NB1, Kelly, NB-1643, } \\
\text { HEK293T }\end{array}$ & MYO10 & - & $\begin{array}{l}\text { miR-129 down-regulates MYO10 levels and then } \\
\text { represses cell proliferation and increased } \\
\text { chemosensitivity. }\end{array}$ & - & (39) \\
\hline miR-1247 & $\begin{array}{l}10 \text { primary NB } \\
\text { and the } \\
\text { corresponding } \\
\text { ANTs }\end{array}$ & SH-SY5Y, SK-N-SH & ZNF346 & - & $\begin{array}{l}\text { miR-1247 markedly decreases cell proliferation and } \\
\text { induces cell cycle arrest and cell death. }\end{array}$ & - & $(40)$ \\
\hline miR-204 & 200 NB tumors & $\begin{array}{l}\text { BE(2)C, SH-SY5Y, } \\
\text { SHEP, Kelly, SK-N-AS, } \\
\text { SK-N-FI, IMR32 }\end{array}$ & MYCN & - & $\begin{array}{l}\text { MYCN binds to the miR-204 promoter and } \\
\text { represses miR-204 transcription. miR-204 directly } \\
\text { binds MYCN mRNA and diminishes MYCN } \\
\text { expression. }\end{array}$ & - & $(41)$ \\
\hline miR-664a-5p & - & SH-SY5Y & - & - & miR-664a-5p enhances neuronal differentiation. & - & $(42)$ \\
\hline miR-124 & - & $\mathrm{M} 17$ & $\begin{array}{l}\text { B-Tubulin } \\
\text { III, MAP2, } \\
\text { SYN, NF- } \\
\text { M, Nestin }\end{array}$ & - & $\begin{array}{l}\text { miR-124 up-regulation increases differentiation in } \\
\text { neuronal lineages. }\end{array}$ & - & $(43)$ \\
\hline miR-505-3p & - & N2a, U251 & SRSF1 & - & $\begin{array}{l}\text { miR-505-3p impedes neural tumor proliferation } \\
\text { driven by SRSF1, solely in serum-reduced } \\
\text { condition. }\end{array}$ & - & $(44)$ \\
\hline miR-513 & $\begin{array}{l}10 \text { primary NB } \\
\text { and matched } \\
\text { ANTs }\end{array}$ & $\begin{array}{l}\text { SK-N-SH, SK-N-BE2, } \\
\text { SH-SY5Y, SK-N-AS, } \\
\text { SK-N-DZ }\end{array}$ & GLS & - & $\begin{array}{l}\text { miR- } 513 c \text { inhibits migration, invasion, and } \\
\text { proliferation. }\end{array}$ & - & $(45)$ \\
\hline miR-205 & $\begin{array}{l}28 \text { tumor and } \\
\text { adjacent } \\
\text { normal tissues } \\
\text { of NB patients }\end{array}$ & $\begin{array}{l}\text { SH-SY5Y, } \\
\text { SK-N-SH, IMR32, BE(2)- } \\
\text { C, HUVEC }\end{array}$ & $\begin{array}{l}\text { CREB1, } \\
\text { BCL-2, } \\
\text { MMP9 }\end{array}$ & - & $\begin{array}{l}\text { Expression of miR-205 is down-regulated in poorly } \\
\text { differentiated NB tissues and those of advanced } \\
\text { stage. }\end{array}$ & - & $(46)$ \\
\hline
\end{tabular}


TABLE 1 | Continued

\begin{tabular}{|c|c|c|c|c|c|c|c|}
\hline miRNA & Specimens & Cell line & $\begin{array}{l}\text { Targets/ } \\
\text { regulators }\end{array}$ & $\begin{array}{l}\text { Signaling } \\
\text { pathway }\end{array}$ & Function & $\begin{array}{l}\text { Effect of } \\
\text { miRNA } \\
\text { down- } \\
\text { regulation } \\
\text { on patient's } \\
\text { prognosis }\end{array}$ & Reference \\
\hline miR-628-3p & $\begin{array}{l}22 \text { primary NB } \\
\text { and } 21 \text { normal } \\
\text { tissues }\end{array}$ & $\begin{array}{l}\text { KCNR, HEK293T, LAN5, } \\
\text { SH-SY5Y, SK-N-SH }\end{array}$ & MYCN & - & $\begin{array}{l}\text { miR-628-3p has a tumor-suppressor characteristic } \\
\text { and down-regulates MYCN. }\end{array}$ & - & $(47)$ \\
\hline miR-17 & - & $\begin{array}{l}\text { SK-N-BE(1)n, LA1-55n, } \\
\text { KCN-83n, BE(2)-M17V, } \\
\text { SK-N-LD, SK-N-HM, BE } \\
\text { (2)-C, LA1-5s, SH-SY5Y, } \\
\text { SMS-LHN, CB-JMN, } \\
\text { SH-EP1, SMS-KCNs }\end{array}$ & $\begin{array}{l}\text { N-myc/ } \\
\text { ELAVL4 }\end{array}$ & - & $\begin{array}{l}\text { miR-17 down-regulates N-myc mRNA and protein } \\
\text { levels, while ELAVL4 up-regulates N-myc and is a } \\
\text { competitive factor for miR-17. }\end{array}$ & - & $(48)$ \\
\hline$m i R-149$ & $\begin{array}{l}117 \mathrm{NB} \\
\text { patients }\end{array}$ & $\begin{array}{l}\text { SH-SY5Y, CHP-212, } \\
\text { IMR-32, SK-N-SH, SK- } \\
\text { N-AS, NB1691, LAN1, } \\
\text { LAN5, } \\
\text { LAN6 }\end{array}$ & Rap1 & - & $\begin{array}{l}\text { Down-regulation of miR-149 expression is } \\
\text { associated with advanced stages of primary NB } \\
\text { tumors and poor OS. }\end{array}$ & Poor OS & (49) \\
\hline \multirow[t]{2}{*}{ miR-137 } & - & $\begin{array}{l}\text { SH-SY5Y, SK-N-SH, } \\
\text { MIR-32, SK-N-BE (2), } \\
\text { normal fibroblast 3T3 } \\
\text { cells, primary normal } \\
\text { human astrocytes }\end{array}$ & $\begin{array}{l}\text { MDR1/ } \\
\text { HDAC8 }\end{array}$ & - & $\begin{array}{l}\text { HDAC8 is overexpressed in NB cells and down- } \\
\text { regulates miR-137 levels, which further decreases } \\
\text { MDR1 and sensitivity to doxorubicin. }\end{array}$ & - & $(50)$ \\
\hline & 88 NB patients & N-2a, SH-SY5Y & $\begin{array}{l}\text { EZH2, } \\
\text { CLU, } \\
\text { NGFR }\end{array}$ & - & $\begin{array}{l}\text { Resveratrol induces miR-137 up-regulation and } \\
\text { reduces } E Z H 2 \text { repression. EZH2 reduction results in } \\
\text { increased } C L U \text { ad NGFR tumor suppressors. }\end{array}$ & Lower OS & (51) \\
\hline $\operatorname{miR}-143$ & - & SH-SY5Y & $\begin{array}{l}-/ \mathrm{NO} \\
\text { RBM3 } \\
\text { p38 }\end{array}$ & - & $\begin{array}{l}\text { RBM3 abolishes the induction of miR-143 and } \\
\text { apoptosis. }\end{array}$ & - & $(52)$ \\
\hline $\operatorname{miR}-410$ & $\begin{array}{l}61 \text { cases of NB } \\
\text { and normal } \\
\text { tissues }\end{array}$ & SK-N-BE(2), NB1691 & $\begin{array}{l}\text { VEGFA } \\
\text { SPARC }\end{array}$ & - & $\begin{array}{l}\text { Concomitant SPARC up-regulation and radiation } \\
\text { restricts tumor growth and angiogenesis by down- } \\
\text { regulating VEGF-A via miR-410. }\end{array}$ & - & (53) \\
\hline miR-93-5p & - & SK-N-AS & VEGF, IL-8 & - & $\begin{array}{l}\text { miR-93-5p is down-regulated in NB cells, which } \\
\text { promotes VEGF and IL-8 and tumorigenesis. }\end{array}$ & - & $(54)$ \\
\hline miR-141 & - & $\begin{array}{l}\text { IMR-32, SH-SY5Y, S-K- } \\
\text { NAS, NB-1691, LAN-5, } \\
\text { LAN-6, HEK293T }\end{array}$ & FUS & - & $\begin{array}{l}\text { miR-141 up-regulation inhibits cancer proliferation, } \\
\text { cell cycle progression, tumor growth, migration, and } \\
\text { rises cisplatin sensitivity. }\end{array}$ & - & $(55)$ \\
\hline miR-497 & $\begin{array}{l}\text { NRC dataset: } \\
365 \text { NB } \\
\text { samples }\end{array}$ & $\begin{array}{l}\text { CHLA-90, SK-N-BE(2), } \\
\text { LA1-5s, SK-N-AS, } \\
\text { HEK293T }\end{array}$ & $\begin{array}{l}\text { WEE1, } \\
\text { CHEK1, } \\
\text { AKT3, } \\
\text { BCL2, } \\
\text { VEGFA }\end{array}$ & - & $\begin{array}{l}\text { miR-497 overexpression reduces the proliferation of } \\
\text { multiple chemoresistant NB cell lines and induced } \\
\text { apoptosis in MYCN-amplified cell lines. Moreover, } \\
\text { miR-497 in NB xenografts diminishes tumor growth } \\
\text { and inhibits vascular permeabilization. }\end{array}$ & $\begin{array}{l}\text { Lower } \\
\text { progression- } \\
\text { free survival }\end{array}$ & $(56)$ \\
\hline miR-451 & $\begin{array}{l}37 \mathrm{NB} \text { and } \\
\text { ANTs }\end{array}$ & SK-N-SH, Gl-LA-N & MIF & - & $\begin{array}{l}\text { miR-451 reduces cell proliferation, invasion, and } \\
\text { migration. Reduction in miR-451 increases tumor } \\
\text { size, dedifferentiation, lymph node metastasis, TNM } \\
\text { stage, and remote metastases. }\end{array}$ & - & $(57)$ \\
\hline miR-203 & $\begin{array}{l}16 \mathrm{NB} \text { and } \\
\text { ANTs }\end{array}$ & SK-N-SH, SH-SY5Y & Sam68 & - & $\begin{array}{l}\text { Up-regulation of miR-203 inhibits the proliferation, } \\
\text { migration, and invasion rates. }\end{array}$ & - & (58) \\
\hline $\begin{array}{l}\text { miR-26a-5p } \\
\text { miR-26b-5p }\end{array}$ & $\begin{array}{l}200 \text { patients } \\
\text { with primary } \\
\text { NB, GSE32664 } \\
\text { dataset: } 75 \\
\text { primary tumors }\end{array}$ & $\begin{array}{l}\text { IMR5-75-shMYCN, } \\
\text { SHEP-MYCN-ER, } \\
\text { MYCN3, HEK293T }\end{array}$ & $\begin{array}{l}\text { LIN28B/ } \\
\text { MYCN }\end{array}$ & - & $\begin{array}{l}\text { MYCN overexpression reduces miR-26a-5p (not in } \\
\text { the transcription stage), and miR-26b-5p results in } \\
\text { LIN28B up-regulation. }\end{array}$ & $\begin{array}{l}\text { Lower OS } \\
\text { rate }\end{array}$ & (59) \\
\hline miR-337-3p & $\begin{array}{l}30 \text { primary } \mathrm{NB} \\
\text { cases and } 21 \\
\text { normal dorsal } \\
\text { ganglia }\end{array}$ & $\begin{array}{l}\text { SK-N-SH, SKN-AS, SH- } \\
\text { SY5Y, SKN-BE(2), } \\
\text { HepG2, PC-3, HeLa, } \\
\text { 786-O, HUVEC }\end{array}$ & $\begin{array}{l}\text { MMP14, } \\
\text { AGO2 }\end{array}$ & - & $\begin{array}{l}\text { miR-337-3p inhibits the activity of } M M P-14 \\
\text { promoter and, its nascent transcription. }\end{array}$ & $\begin{array}{l}\text { Lower OS } \\
\text { rate }\end{array}$ & (60) \\
\hline miR-362-5p & $\begin{array}{l}12 \text { metastatic } \\
\text { and } 12 \text { primary } \\
\text { NB tissues }\end{array}$ & $\begin{array}{l}\text { SH-SY5Y, IMR-32, } \\
\text { HEK293 }\end{array}$ & PI3K-C2 $\beta$ & - & $\begin{array}{l}\text { Overexpression of miR-362-5p inhibits cell } \\
\text { proliferation, tumor growth, migration, and invasion } \\
\text { of NB cells. }\end{array}$ & - & $(61)$ \\
\hline miR-659-3p & $\begin{array}{l}22 \text { bone } \\
\text { marrow }\end{array}$ & HTLA-230, SH-SY5Y & $\begin{array}{l}\text { CNOT1, } \\
\text { AKT3, }\end{array}$ & - & $\begin{array}{l}\text { Inhibiting miR-659-3p results in over-expressed } \\
\text { CNOT1 and down-regulated AKT3, BCL2, CYR61, }\end{array}$ & - & $(62)$ \\
\hline
\end{tabular}


TABLE 1 | Continued

\begin{tabular}{|c|c|c|c|c|c|c|c|}
\hline miRNA & Specimens & Cell line & $\begin{array}{l}\text { Targets/ } \\
\text { regulators }\end{array}$ & $\begin{array}{l}\text { Signaling } \\
\text { pathway }\end{array}$ & Function & $\begin{array}{l}\text { Effect of } \\
\text { miRNA } \\
\text { down- } \\
\text { regulation } \\
\text { on patient's } \\
\text { prognosis }\end{array}$ & Reference \\
\hline & $\begin{array}{l}\text { infiltrating } \\
\text { samples, } 22 \\
\text { primary tumor } \\
\text { samples }\end{array}$ & & $\begin{array}{l}\text { BCL2, } \\
\text { THSB2, } \\
\text { CYR61 }\end{array}$ & & $\begin{array}{l}\text { and THSB2, (all involved in focal adhesion) as } \\
\text { observed in bone marrow infiltrating NB cells. }\end{array}$ & & \\
\hline $\begin{array}{l}\text { miR-182-5p } \\
\text { miR-432-5p }\end{array}$ & $\begin{array}{l}100 \mathrm{NB} \\
\text { patients }\end{array}$ & $\begin{array}{l}\text { NGP, NGP-Iv-hp53, } \\
\text { NGP-IV-mp53, SK-N-AS, } \\
\text { SK-N-Be(2c), IMR-32, } \\
\text { IMR-32-Iv-hp53, IMR- } \\
\text { 32-IV-mp53. NGP/IMR- } \\
\text { IV-hp53, NGP/IMR-IV- } \\
\text { mp53 }\end{array}$ & -/p53 & - & $\begin{array}{l}\text { Overexpression of miR-182-5p and miR-432-5p } \\
\text { increases apoptosis rate and promotes neuronal } \\
\text { differentiation. }\end{array}$ & $\begin{array}{l}\text { - } \\
\text { Lower } \\
\text { progression- } \\
\text { free survival }\end{array}$ & (63) \\
\hline miR-449a & $\begin{array}{l}\text { Versteeg } \\
\text { cohort: } 88 \mathrm{NB} \\
\text { patients, Kocak } \\
\text { cohort: } 476 \mathrm{NB} \\
\text { patients }\end{array}$ & $\begin{array}{l}\mathrm{BE}(2)-\mathrm{C}, \mathrm{SKNBE} \text { and BE } \\
\text { (2)-M17, LAN6, KELLY }\end{array}$ & $\begin{array}{l}\text { MFAP4, } \\
\text { PKP4, } \\
\text { TSEN15, } \\
\text { CDK6, } \\
\text { LEF1 }\end{array}$ & - & $\begin{array}{l}\text { miR-449a impedes NB cell survival and proliferation } \\
\text { by increasing cell differentiation and cell cycle arrest. }\end{array}$ & - & (64) \\
\hline miR-520f & $\begin{array}{l}\text { GSE16476 } \\
\text { dataset: } 237 \\
\text { NB patients, } 3 \\
\text { FFPE matched } \\
\text { pre-treatment } \\
\text { and post- } \\
\text { treatment }\end{array}$ & SK-N-AS & NAIP & - & $\begin{array}{l}\text { miR-520f down-regulation increases NAIP levels. } \\
\text { miR-520f levels are determined to be significantly } \\
\text { lower in post-chemotherapy treatment. }\end{array}$ & - & (65) \\
\hline miR-542-3p & $\begin{array}{l}69 \text { primary NB } \\
\text { tumors }\end{array}$ & $\begin{array}{l}\text { IMR-32, SHEP, SK-N- } \\
\text { BE and WAC II, } \\
\text { HEK293, SK-N-SH, SH- } \\
\text { SY5Y }\end{array}$ & Survivin & - & $\begin{array}{l}\text { Up-regulation of miR-542-3p in NB cells diminishes } \\
\text { the cell viability and proliferation, induced apoptosis, } \\
\text { and down-regulates Survivin. }\end{array}$ & $\begin{array}{l}\text { Lower } \\
\text { survival rate }\end{array}$ & (66) \\
\hline
\end{tabular}

of studies which described down-regulation of miRNAs in neuroblastoma.

Schulte et al. have identified seven miRNAs whose expressions have been increased by MYCN in vitro and are over-expressed in primary neuroblastomas that harbor MYCN amplification. Notably, three of them were from the miR-106a and miR-17 clusters whose expressions are controlled by c-Myc. They also demonstrated upregulation of miR-221 by MYCN in neuroblastoma (67). Montana et al. have shown transactivation of the miRNA 17-5p-92 cluster by MYCN. These miRNAs have further been demonstrated to suppress expression of p21 and BIM, thus influencing cell cycle transition and apoptosis, respectively. Notably, forced up-regulation of miRNA 17-5p-92 cluster in neuroblastoma cell lines that do not harbor MYCN amplification enhances their tumorigenic potential in animal models. On the other hand, suppression of miR-17-5p attenuates the proliferation of $M Y C N$-amplified neuroblastoma cells via up-regulation of $\mathrm{p} 21$ and BIM. Over-expression of miR$17-5 \mathrm{p}$ has also been verified in primary neuroblastoma patients especially those with $M Y C N$ amplification and poor clinical outcome (68). miR-640, miR-543, miR-624-3p, and miR-196-b are among up-regulated miRNAs in neuroblastoma. Notably, these miRNAs target ING5 transcript. miRNA-ING5-histone acetylation axis has been recognized as the main route through which two anticancer drugs namely a histone deacetylase inhibitor and a proteasome inhibitor block progression of neuroblastoma (69). miR-1303 is another over-expressed miRNA in neuroblastoma.
Up-regulation of this miRNA enhanced proliferation of neuroblastoma cells through targeting GSK3 $\beta$ and SFRP1. miR1303 also increased levels of MYC and CyclinD1, and diminished p21 and p27 levels (70). Table 2 lists up-regulated miRNAs in neuroblastoma.

Aberrant expression of miRNAs in neuroblastoma samples can be used as biomarkers for prediction of the course of malignancy. For instance, down-regulation of miR-490-5p has been correlated with INSS stage, lymph node involvement, and poor clinical outcome of patients with neuroblastoma (22). Similarly, decreased expression of miR-186, let-7, miR-497 and miR-432-5p predicts lower survival rates $(31,34,56,63)$. Table 3 reviews the results of studies which evaluated this aspect of miRNAs.

\section{Dysregulated IncRNAs in Neuroblastoma}

LncRNAs can regulate expression of genes via different mechanisms including alterations in chromatin configuration, modulation of transcription, splicing, mRNA stability and bioavailability as well as post-translational modifications (83). Therefore, they contribute in the pathogenesis of human cancers. Prajapati et al. have analyzed RNA-seq data of a number of neuroblastoma samples to recognize their differential expression in among primary neuroblastoma, relapsed ones and metastasized tumors. They reported up-regulation of RFPL1S, 
TABLE 2 | Up-regulated miRNAs in neuroblastoma (NB, neuroblastoma; OS, overall survival).

\begin{tabular}{|c|c|c|c|c|c|c|c|}
\hline miRNA & $\begin{array}{l}\text { Number of clinical } \\
\text { samples }\end{array}$ & Assessed cell line & $\begin{array}{l}\text { Targets/ } \\
\text { regulators }\end{array}$ & $\begin{array}{l}\text { Signaling } \\
\text { pathway }\end{array}$ & Function & $\begin{array}{l}\text { Effect of } \\
\text { miRNA up- } \\
\text { regulation on } \\
\text { patients' } \\
\text { prognosis }\end{array}$ & Ref \\
\hline miR-25 & $\begin{array}{l}\text { Versteeg dataset: } 88 \\
\text { samples, Kocak } \\
\text { dataset: } 649 \text { samples, } \\
\text { SEQC dataset: } 498 \\
\text { samples }\end{array}$ & SH-SY5Y & $\begin{array}{l}\text { Gsk3ß/ } \\
\text { SLC34A2 }\end{array}$ & Wnt & $\begin{array}{l}\text { SLC34A2 inhibits the stemness of NB cells via the miR- } \\
\text { 25-Gsk3 } \beta \text { axis. }\end{array}$ & - & (71) \\
\hline $\begin{array}{l}\text { miR-640, } \\
\text { miR-543, } \\
\text { miR-624- } \\
\text { 3p, miR- } \\
196-b\end{array}$ & $50 \mathrm{NB}$ tissues & $\begin{array}{l}\text { SH-SY5Y, SK-N-AS, } \\
\text { NGP, SK-N-BE2 }\end{array}$ & ING5 & - & $\begin{array}{l}\text { Suberoylanilide hydroxamic acid downregulates these } \\
\text { miRNAs to induce ING5 overexpression. }\end{array}$ & - & (69) \\
\hline $\begin{array}{l}\operatorname{miR}-3613 \\
-3 p\end{array}$ & - & $\begin{array}{l}\text { BE(2)-C, Kelly, IMR } \\
-32, \text { SK-N-SH, CHP } \\
-134, \text { LAN-1, LAN-5, } \\
\text { PC3 }\end{array}$ & $\begin{array}{l}\text { APAF1, } \\
\text { DICER, } \\
\text { DFFB, } \\
\text { VHL, NF1/ } \\
\text { MCPIP1 }\end{array}$ & $\begin{array}{l}\text { Wnt, } \\
\text { TGF } \beta \text {, Akt }\end{array}$ & $\begin{array}{l}\text { The up-regulation of miR-3613-3p increases viability but } \\
\text { reduces the apoptosis of NB cells. }\end{array}$ & - & (72) \\
\hline \multirow[t]{2}{*}{$\begin{array}{l}\operatorname{miR}-181 a / \\
b\end{array}$} & $\begin{array}{l}32 \text { primary NB tissues } \\
\text { and } 6 \text { gangliocytoma } \\
\text { tissues as controls }\end{array}$ & $\begin{array}{l}\text { SK-SY5Y, SK-N-SH, } \\
\text { BE(2) C, IMR-32, } \\
\text { HUVEC, HEK293T }\end{array}$ & $\mathrm{ABI} 1$ & - & $\begin{array}{l}\text { High miR-181a/b expression markedly enhances the } \\
\text { proliferation, tumorigenesis, progression, migration, and } \\
\text { invasion of NB cells, though it reduces the apoptosis } \\
\text { rate. MYCN amplification and miR-181a expression are } \\
\text { correlated. }\end{array}$ & - & (73) \\
\hline & - & SH-SY5Y & $\begin{array}{l}\text { p38MAPK } \\
\text { triptolide }\end{array}$ & $N F-\kappa B$ & $\begin{array}{l}\text { Through down-regulating miR-181a/b level, Triptolide } \\
\text { inhibits cell viability, proliferation, and migration, but } \\
\text { induces cell apoptosis. }\end{array}$ & - & (74) \\
\hline miR-181a & - & $\begin{array}{l}\text { SH-SY5Y, A172, } \\
\text { U251 }\end{array}$ & PARK2 & - & $\begin{array}{l}\text { miR-181a suppresses mitochondrial uncoupling agents- } \\
\text { induced mitophagy by decreasing the destruction of } \\
\text { mitochondrial proteins. }\end{array}$ & - & $(75)$ \\
\hline miR-221 & $31 \mathrm{NB}$ tissues & $\begin{array}{l}\text { SK-N-AS, SK-N-DZ, } \\
\text { IMR-32, HEK293T, } \\
\text { SH-SY5Y }\end{array}$ & $\begin{array}{l}\text { LEF1, } \\
\text { NLK, p21, } \\
\text { p27, p57 }\end{array}$ & Wnt & $\begin{array}{l}\text { miR-221 diminishes LEF1 phosphorylation but up- } \\
\text { regulates MYCN. Overexpression of miR-221 enhances } \\
\text { the cell cycle transition especially in S-phase, promoting } \\
\text { the proliferation of NB cells. }\end{array}$ & $\begin{array}{l}\text { Poor survival } \\
\text { rate }\end{array}$ & (76) \\
\hline \multirow[t]{2}{*}{ miR-558 } & $\begin{array}{l}30 \text { primary NB and } 10 \\
\text { ganglioneuroblastoma } \\
\text { samples, GSE62564 } \\
\text { database: } 498 \text { NB } \\
\text { cases }\end{array}$ & $\begin{array}{l}\text { NB-1643, SK-N-BE } \\
\text { (2), NB-1691, IMR32, } \\
\text { BE(2)-C, SK-N-AS, } \\
\text { SH-SY5Y, SK-N-SH, } \\
\text { HUVEC }\end{array}$ & $\begin{array}{l}\text { AGO2, } \\
\mathrm{HIF}-2 \alpha\end{array}$ & - & $\begin{array}{l}\text { miR-558 enhances the proliferation, invasion, metastatic } \\
\text { capacities, and angiogenic potential. }\end{array}$ & Poor OS & (77) \\
\hline & 30 primary NB cases & $\begin{array}{l}\text { SK-N-SH, SK-N-AS, } \\
\text { SH-SY5Y, SK-N-BE } \\
\text { (2), HUVEC }\end{array}$ & $\begin{array}{l}\text { HPSE, } \\
\text { VEGF, } \\
\text { AGO1 }\end{array}$ & - & $\begin{array}{l}\text { Knock-down of endogenous miR-558 reduced the } \\
\text { proliferation, invasion, metastasis, and angiogenic } \\
\text { potential. }\end{array}$ & - & $(78)$ \\
\hline miR-1303 & $\begin{array}{l}8 \mathrm{NB} \text { and adjacent } \\
\text { normal nerve tissues }\end{array}$ & $\begin{array}{l}\text { U343, SK-N-SH, SH- } \\
\text { SY5Y, LAN5, IMR-32, } \\
\text { SH-EP }\end{array}$ & $\begin{array}{l}\text { GSK3 } \beta \\
\text { SFRP1, } \\
\text { p21, p27, } \\
\text { MYC, } \\
\text { CyclinD1 }\end{array}$ & - & $\begin{array}{l}\text { miR-1303 overexpression results in up-regulated } \\
\text { proliferation rates. }\end{array}$ & - & $(70)$ \\
\hline miR-19b & - & SH-SY5Y, BE(2)-M17 & $\begin{array}{l}\text { p-AKT, } \\
\text { PTEN }\end{array}$ & mTOR & $\begin{array}{l}\text { AZD8055 significantly reduces miR-19b and p-AKT } \\
\text { expression and enhances the cytotoxic activity of mTOR } \\
\text { inhibitors and PTEN levels. miR-19b overexpression } \\
\text { reverses mTOR inhibitors toxicity and cell viability. }\end{array}$ & - & (79) \\
\hline miR-21 & & & $\mathrm{CHL} 1$ & & $\begin{array}{l}\text { miR-21 promotes the proliferation and invasion of NB } \\
\text { cells. }\end{array}$ & & (80) \\
\hline
\end{tabular}

PPP1R26-AS1, RP11-439E19.3, CASC15, AC004540.5, and CTD-2881E23.2 while down-regulation of USP3-AS1, CHRM3-AS2 and RP6-99M1.2 in tumor cells compared with the corresponding non-tumor mononuclear cells isolated from bone marrow (MNCs). Moreover, expression of theses upregulated lncRNAs along with ZRANB2-AS2 and LINC00511 were increased in the disseminated tumor cells (DTCs) compared with the corresponding MNCs. They suggested CASC15, PPP1R26-AS1, and USP3-AS1 lncRNAs as putative markers in clinical investigations in this type of pediatric cancer (84). Pandey et al. have assessed transcript signature of low-risk and high-risk neuroblastoma samples. They have reported association between a certain lncRNA namely neuroblastoma associated transcript-1 (NBAT-1) and prognosis of neuroblastoma. Altered expression of this lncRNA between the mentioned groups of neuroblastoma has been attributed to CpG methylation and the presence of a certain functional polymorphism on chr 6p22. Mechanistically, NBAT-1 down-regulation enhances proliferation 
TABLE 3 | Diagnostic importance of miRNAs in neuroblastoma (NB, neuroblastoma; OS, overall survival; EFS, event-free survival).

Sample number

miR-490-5p expression in NB patients: 21 high and 51 low

miR-323a-5p expression: high in 228 and low in 25 NB patients

miR-2110 expression in NB patients, derived from SEQC dataset: high=406, low=92

miR-186 expression in NB patients: 235 high and 263 for EFS, 298 high and 200 low for

OS

miR-149 expression in NB patients: low $=59$, high $=58$

miR-221 expression in NB patients: low $=17$, high $=14$

miR-181c expression: high $=326$, low $=172$

miR-558 expression in two sets of samples: 13 low and 17 high, 170 low and 328 high Let-7 expression in NB patients: normal levels $=60$, loss of Let- $7=112$

70 patients with NB, divided into 3 groups based on their expression level of miR-21 and risk: low $=22$, moderate $=23$, high $=25$

miR-497 expression in NB patients from NRC dataset: high=100, low=228

miR-26a-5p expression in NB patients: high $=44$, low $=48$ miR-26b-5p expression in NB patients: high $=50$, low $=42$ miR-337-3p expression in 30 NB patients: 17 high and 13 low miR-432-5p expression in 100 NB patients

miR-137 expression in NB patients: 17 high and 71 low miR-542-3p expression level in NB patients: 34 high and 34 low

miR-34a expression in NB patients: 15 high and 15 low
Kaplan-Meier analysis

Reference

Higher miR-490-5p expression levels markedly correlate with higher survival rate.

Higher expression levels of miR-323a-5p expression correlates with higher OS rate.

Higher expression levels of miR-2110 correlate with lower OS.

Low levels of miR-186 correlate with poor OS and EFS.

Higher miR-149 expression level significantly correlates with higher OS rate.

miR-221 expression level negatively correlates with survival ratio.

Higher miR-181c significantly correlates with higher OS in NB patients.

Higher expression negatively correlates with the OS rate. Loss of Let-7 expression correlates with lower OS rate.

In patients with NB, higher miR-21 expression correlated with lower rates of OS.

Lower miR-497 expression correlates with lower progression-free survival rates.

Lower miR-26a-5p and miR-26b-5p expression correlate with lower OS rate.

Lower miR-337-3p levels correlate with lower OS rate. Lower miR-432-5p expression levels relates to lower cumulative survival.

miR-137 expression negatively correlates with OS rate. miR-542-3p over-expression significantly correlates with better survival rate.

Higher miR-34a level significantly correlates with better survival rate. and invasion of neuroblastoma cells through suppression of expression of target genes as well as induction of expression of neuronal-specific transcription factor NRSF/REST (85). Liu et al. have reported co-amplification of the $\ln C U S M y c N$ with $M Y C N$ in a portion of human neuroblastoma samples. This IncRNA has been shown to bind with the RNA-binding protein NonO, resulting in $\mathrm{N}$-Myc up-regulation (86). Barnhill et al. have revealed that low levels of CAI2 expression in normal tissues in spite of its overexpression in the majority of tumor cell lines with a normal 9p21 locus. This lncRNA has been suggested to modulate expression of p16 and/or ARF. CAI2 expression has been higher in advancedstage neuroblastomas in an independent manner from $M Y C N$ amplification (87). Watters et al. have shown modulation of expression of several transcribed Ultra-conserved regions ( $\mathrm{T}$ UCRs) in response to all-trans-retinoic acid (ATRA). Among these transcripts has been the IncRNA T-UC.300A which has imperative impacts in the regulation of cell proliferation, invasion and the suppression of differentiation of neuroblastoma cells before exposure to ATRA (88). Yu et al. have identified a transcript which has been over-expressed in neuroblastoma and named it the noncoding RNA expressed in aggressive neuroblastoma (ncRAN). Over-expression of this transcript has been associated with poor survival of patients. This lncRNA has been mapped to the region of $17 q$ which is amplified in neuroblastoma and exerts oncogenic effects in this type of cancer (89). Tables $\mathbf{4}$ and $\mathbf{5}$ enlist over-expression and decreased expression lncRNAs in neuroblastoma, respectively.

Dysregulation of several lncRNAs in neuroblastoma samples has been correlated with survival of patients. For instance, high levels of DLX6-AS1, lncNB1, LINC01296, SNHG16 and RMRP expression have been linked with poor prognosis and lower survival $(90,92,94,95,104)$. Table 6 summarizes the results of studies which assessed correlation between expression levels of lncRNAs and survival of patients with neuroblastoma.

\section{Expression and Function of circRNAs in Neuroblastoma}

Circular RNAs (circRNAs) constitute a group of ncRNAs which are produced from exons or introns through construction of covalently-closed circles (134). Recent studies have shown dysregulation of this type of ncRNAs in cancers. For instance, circDGKB has been shown to be over-expressed in neuroblastoma tissues versus normal dorsal root ganglia. Notably, overexpression of this circRNA has been an indicator of poor survival of these patients. Mechanistically, circDGKB enhances cell proliferation, migration and invasion of neuroblastoma cells while inhibiting cell apoptosis. Moreover, up-regulation of circDGKB reduced expression level of miR-873 and increased GLI1 expression (135). Table 7 recapitulates the results of studies which assessed function of circRNAs in neuroblastoma.

\section{Polymorphisms Within ncRNAs and Risk of Neuroblastoma}

Single nucleotide polymorphisms (SNPs) within lncRNAs or miRNAs can modulate expression or activity of these transcripts, thus being implicated in the development of neuroblastoma. The 
TABLE 4 | Up-regulated IncRNAs in neuroblastoma (ANT, adjacent normal tissue; NB, Neuroblastoma; EMT, epithelial-mesenchymal transition; OS, overall survival; EFS, event-free survival).

\begin{tabular}{|c|c|c|c|c|c|c|c|}
\hline IncRNA & Specimens & Cell lines & Targets/regulators & $\begin{array}{l}\text { Signaling } \\
\text { pathway }\end{array}$ & Function & $\begin{array}{l}\text { Effect of } \\
\text { IncRNA up- } \\
\text { regulation } \\
\text { on patient's } \\
\text { prognosis }\end{array}$ & Ref \\
\hline \multirow[t]{2}{*}{ DLX6AS1 } & $\begin{array}{l}70 \text { pairs of } \\
\text { primary NB and } \\
\text { ANTs }\end{array}$ & $\begin{array}{l}\text { SK-N-SH, SH-SY5Y, SK- } \\
\text { N-AS, SK-N-BE, } \\
\text { HEK293T }\end{array}$ & miR-497-5p, YAP1 & - & $\begin{array}{l}\text { DLX6-AS1 knock-down results in diminished } \\
\text { proliferation rate, tumor proliferation, migration, } \\
\text { EMT, and invasion. }\end{array}$ & $\begin{array}{l}\text { Poor } \\
\text { prognosis } \\
\text { and OS }\end{array}$ & (90) \\
\hline & $\begin{array}{l}31 \mathrm{NB} \text { and } \\
\text { ANTs }\end{array}$ & $\begin{array}{l}\text { SK-N-SH, LAN-6, } \\
\text { HUVEC }\end{array}$ & $\begin{array}{l}\text { miR-506-3p, STAT2, } \\
\text { CDK1, Cyclin D1 }\end{array}$ & - & $\begin{array}{l}\text { DLX6-AS1 silencing inhibits proliferation, tumor } \\
\text { growth, cell cycle, and glycolysis. }\end{array}$ & - & (91) \\
\hline IncNB1 & $\begin{array}{l}\text { SEQC-RPM- } \\
\text { seqcnb1 } \\
\text { dataset: } 493 \\
\text { NB tissues }\end{array}$ & $\begin{array}{l}\text { BE(2)-C, IMR32, SY5Y, } \\
\text { SHEP, HEK293T }\end{array}$ & $\begin{array}{l}\text { RPL35, E2F1, } \\
\text { DEPDC1B, ERK, n-Myc }\end{array}$ & - & $\begin{array}{l}\text { LncNB1 down-regulation abrogates clonogenic } \\
\text { capacity and leads to NB tumor regression. }\end{array}$ & Lower OS & (92) \\
\hline DEIN & $\begin{array}{l}\text { Case study of a } \\
\text { monozygotic } \\
\text { twin with NB }\end{array}$ & - & HAND2 & - & $\begin{array}{l}\text { Both twin liver tumors had a } 4 \text { q34.1 } \\
\text { amplification of DEIN, which is strongly linked to } \\
\text { HAND2. HAND2 functions as an essential } \\
\text { regulator of neurogenesis. }\end{array}$ & - & (93) \\
\hline LINC01296 & $\begin{array}{l}28 \text { patients with } \\
\text { primary NB, R2: } \\
\text { Genomics } \\
\text { Analysis } \\
\text { and } \\
\text { Visualization } \\
\text { Platform for } 88 \\
\text { NB patients }\end{array}$ & - & - & - & $\begin{array}{l}\text { Over-expression of LINC01296 was associated } \\
\text { with age>18 month and advanced INSS stage. } \\
\text { Moreover, LINC01296 over-expression is } \\
\text { correlated with larger tumor size, elevated } \\
\text { serum lactate dehydrogenase level, and serum } \\
\text { neuron-specific enolase level. }\end{array}$ & $\begin{array}{l}\text { Poor } \\
\text { prognosis } \\
\text { and OS }\end{array}$ & (94) \\
\hline \multirow[t]{5}{*}{ SNHG16 } & $\begin{array}{l}40 \text { patients with } \\
\text { NB, GSE62564 } \\
\text { dataset: } 498 \\
\text { NB patients }\end{array}$ & SH-SY5Y & - & - & $\begin{array}{l}\text { SNHG16 down-regulation inhibits proliferation, } \\
\text { migration, and induces cell cycle arrest at the } \\
\text { G0/G1 phase. SNHG16-related RNA binding } \\
\text { proteins partake in controlling mRNA metabolic } \\
\text { processes, gene silencing, mRNA transport, } \\
\text { RNA splicing, and translation. }\end{array}$ & $\begin{array}{l}\text { Poor OS } \\
\text { and EFS }\end{array}$ & (95) \\
\hline & 76 NB tissues & $\begin{array}{l}\text { SK-N-AS, SK-N-SH, SK- } \\
\text { N-AS-R, SK-NSH-R }\end{array}$ & $\begin{array}{l}\text { miR-338-3p, PLK4, } \\
\text { MRP1, p-glycoprotein }\end{array}$ & PI3K/AKT & $\begin{array}{l}\text { In cisplatin-resistant NB tissues and cells. } \\
\text { SNHG16 is up-regulated, while miR-338-3p is } \\
\text { down-regulated. }\end{array}$ & - & (96) \\
\hline & $\begin{array}{l}48 \text { NB and } 38 \\
\text { ANTs }\end{array}$ & $\begin{array}{l}\text { SK-N-SH, IMR-32, SK- } \\
\text { N-AS, SK-N-DZ, HUVEC }\end{array}$ & HOXA7, miR-128-3p & - & $\begin{array}{l}\text { SNHG16 silencing represses proliferation, } \\
\text { migration, and invasion but boosts apoptosis. }\end{array}$ & - & (97) \\
\hline & $\begin{array}{l}30 \mathrm{NB} \text { and } 30 \\
\text { ANTs }\end{array}$ & $\begin{array}{l}\text { SKNBE-2, SK-N-SH, } \\
\text { HEK293, LAN-5 }\end{array}$ & miR-542-3p, HNF4 $\alpha$ & $\begin{array}{l}\text { RAS/RAF/ } \\
\text { MEK/ERK }\end{array}$ & $\begin{array}{l}\text { The Knock-down of SNHG16 or HNF } 4 \alpha \\
\text { impedes proliferation, migration, invasion, and } \\
\text { EMT. }\end{array}$ & - & (98) \\
\hline & $\begin{array}{l}45 \mathrm{NB} \text { and } \\
\text { ANTs }\end{array}$ & $\begin{array}{l}\text { LAN-1, SHEP, SKN-SH, } \\
\text { IMR-32, HUVEC }\end{array}$ & miR-542-3p, ATG5 & - & $\begin{array}{l}\text { The knock-down of SNHG16 diminishes } \\
\text { proliferation, migration, invasion, autophagy, } \\
\text { and tumor growth. }\end{array}$ & Lower OS & (99) \\
\hline MIAT & - & Neuro2A & $\begin{array}{l}\text { caspase-3, miR-211, } \\
\text { GDNF }\end{array}$ & - & MIAT overexpression lowers the apoptosis rate. & - & $(100)$ \\
\hline \multirow[t]{3}{*}{ SNHG7 } & & & miR-653-5p, STAT2 & & $\begin{array}{l}\text { SNHG7-miR-653-5p-STAT2 loop is involved in } \\
\text { regulation of NB progression. }\end{array}$ & & (101) \\
\hline & $\begin{array}{l}26 \mathrm{NB} \text { and } \\
\text { ANTs }\end{array}$ & $\begin{array}{l}\text { SK-N-AS, LAN-6, } \\
\text { HUVEC }\end{array}$ & miR-329-3p, MYO10 & - & $\begin{array}{l}\text { Silencing of SNHG7 reduced cisplatin } \\
\text { resistance and suppressed cisplatin-induced } \\
\text { autophagy. }\end{array}$ & - & (102) \\
\hline & $\begin{array}{l}45 \mathrm{NB} \text { and } \\
\text { ANTs }\end{array}$ & $\begin{array}{l}\text { SH-SY5Y, SK-N-SH, NB- } \\
\text { 1, SK-N-AS, HUVEC }\end{array}$ & $\begin{array}{l}\text { miR-323a-5p, miR- } \\
\text { 342-5p, CCND1 }\end{array}$ & - & $\begin{array}{l}\text { SNHG7 knock down repressed migration, } \\
\text { invasion, and glycolysis. }\end{array}$ & $\begin{array}{l}\text { Poor } \\
\text { prognosis } \\
\text { and OS }\end{array}$ & $(103)$ \\
\hline RMRP & $\begin{array}{l}44 \text { cases of } \\
\text { neonatal NB } \\
\text { and ANTs }\end{array}$ & $\begin{array}{l}\text { NB-1, SK-N-AS, } \\
\text { HEK293T }\end{array}$ & miR-206, TACR1 & ERK1/2 & $\begin{array}{l}\text { RMRP knock-down lessens proliferation, } \\
\text { migration, and invasion rates. RMRP expression } \\
\text { is markedly increased in patients with advanced } \\
\text { neonatal NB versus early stages. }\end{array}$ & Poor OS & $(104)$ \\
\hline \multirow[t]{2}{*}{ SNHG1 } & - & $\begin{array}{l}\text { SK-N-DZ, SK-N-BE(2)C, } \\
\text { SK-N-AS }\end{array}$ & $\begin{array}{l}\text { MATR3, YBX1, } \\
\text { HNRNPL }\end{array}$ & - & $\begin{array}{l}\text { SNHG1 significantly elevates ribonucleoprotein } \\
\text { complex biogenesis, RNA processing, and } \\
\text { RNA splicing. }\end{array}$ & - & $(105)$ \\
\hline & $\begin{array}{l}\text { GSE62564 } \\
\text { dataset: } 493 \\
\text { NB patients, }\end{array}$ & $\begin{array}{l}\text { SK-N-DZ, SK-N-SH, SK- } \\
\text { N-BE(2)-C, SK-N-AS, } \\
\text { SK-N-F1 }\end{array}$ & $-/ \mathrm{MYCN}$ & - & MYCN amplification up-regulates SNHG1. & $\begin{array}{l}\text { Poor OS } \\
\text { and EFS }\end{array}$ & $(106)$ \\
\hline
\end{tabular}


TABLE 4 | Continued

\begin{tabular}{|c|c|c|c|c|c|c|c|}
\hline IncRNA & Specimens & Cell lines & Targets/regulators & $\begin{array}{l}\text { Signaling } \\
\text { pathway }\end{array}$ & Function & $\begin{array}{l}\text { Effect of } \\
\text { IncRNA up- } \\
\text { regulation } \\
\text { on patient's } \\
\text { prognosis }\end{array}$ & Ref \\
\hline & $\begin{array}{l}\text { GSE12460 } \\
\text { dataset: } 47 \mathrm{NB} \\
\text { patients }\end{array}$ & & & & & & \\
\hline $\begin{array}{l}\text { GALNT8 } \\
\text { GAU1 }\end{array}$ & $\begin{array}{l}\text { TCGA dataset: } \\
88 \text { NB cases }\end{array}$ & SK-N-AS, HEK293T & $\begin{array}{l}\text { TCEA1, RBMX, MCM2, } \\
\text { CBX3 }\end{array}$ & - & $\begin{array}{l}\text { Suppressing the GAU1/GALNT8 cluster hinders } \\
\text { tumor progression and growth. GAU1 recruits } \\
\text { TCEA1 to activate GALNT8 expression. }\end{array}$ & Poor OS & $(107)$ \\
\hline $\begin{array}{l}\text { MYCNOS- } \\
01\end{array}$ & 88 NB samples & KELLY, SY5Y & MYCN & - & $\begin{array}{l}\text { MYCNOS-01 suppresses MYCN protein levels. } \\
\text { The suppression of MYCNOS-01 or MYCN } \\
\text { expression reduced cell proliferation and } \\
\text { viability. }\end{array}$ & - & $(108)$ \\
\hline pancEts-1 & $\begin{array}{l}42 \text { NB patients } \\
\text { and } 88 \text { NB } \\
\text { cases from } \\
\text { GSE16476 } \\
\text { dataset }\end{array}$ & $\begin{array}{l}\text { NB-1643, SK-N-BE(2), } \\
\text { NB-1691, IMR32, BE(2)- } \\
\text { C, (SK-N-AS, SH-SY5Y, } \\
\text { SK-N-SH }\end{array}$ & hnRNPK, $\beta$-catenin & - & $\begin{array}{l}\text { PancEts- } 1 \text { increases the proliferation, invasion, } \\
\text { and metastasis of NB cells. pancEts- } 1 \text { binds to } \\
\text { hnRNPK to enhances its interplay with } \beta \text { - } \\
\text { catenin and stabilizes the } \beta \text {-catenin. }\end{array}$ & Poor survival & $(109)$ \\
\hline \multirow[t]{3}{*}{ MALAT1 } & $\begin{array}{l}15 \text { normal } \\
\text { tissues, } 19 \\
\text { primary NB, and } \\
28 \text { metastatic } \\
\text { NB tissues }\end{array}$ & $\begin{array}{l}\text { NGP, } \\
\text { SH-SY5Y, NMB, } \\
\text { SHEP21N, SKNAS, } \\
\text { SHEP2, HEK293T }\end{array}$ & $\mathrm{Axl}, \mathrm{AKT}, \mathrm{ERK} 1 / 2$ & - & $\begin{array}{l}\text { MALAT1 overexpression increases invasion and } \\
\text { migration. }\end{array}$ & - & (110) \\
\hline & - & BE(2)-C, HUVEC & FGF2 & - & $\begin{array}{l}\text { MALAT1 significantly promotes cell migration, } \\
\text { invasion, and vasculogenesis. }\end{array}$ & - & $(111)$ \\
\hline & - & $\mathrm{BE}(2)-\mathrm{C}, \mathrm{CHP} 134$ & -/N-Myc, JMJD1A & - & $\begin{array}{l}\text { Migration and invasion rate increase following } \\
\text { MALAT1 overexpression. }\end{array}$ & - & $(112)$ \\
\hline GAS5 & - & $\begin{array}{l}\text { IMR-32, CHLA-122, } \\
\text { SMS-KAN, SK-N-Be(1), } \\
\text { KCNA, NPE, SK-N-AS, } \\
\text { LA-N-6, CHLA-15, SK-N- } \\
\text { FI, CHLA-171, NB-EBc1, } \\
\text { CHLA-42, GI-M-EN }\end{array}$ & $\begin{array}{l}\text { p53, BRCA1, } \\
\text { GADD45A, HDM2 }\end{array}$ & - & $\begin{array}{l}\text { GAS5 loss results in defects in cell proliferation, } \\
\text { apoptosis, but induces cell cycle arrest. }\end{array}$ & - & $(113)$ \\
\hline $\begin{array}{l}\text { HCN3 } \\
\text { linc01105 }\end{array}$ & $\begin{array}{l}\text { Tumor and } \\
\text { para-tumor } \\
\text { tissue samples } \\
(\mathrm{n}=6)\end{array}$ & $\mathrm{BE}(2)-\mathrm{C}$ & BID, Noxa, HIF-1 $\alpha$ & - & $\begin{array}{l}\text { Linc01105 knock-down increases HIF-1 } \alpha \text { and } \\
\text { promotes cell proliferation. In contrast, } \\
\text { linc01105 and HCN3 knock-down increase the } \\
\text { apoptosis rate. }\end{array}$ & - & $(114)$ \\
\hline \multirow[t]{2}{*}{ IncUSMycN } & $\begin{array}{l}\text { Versteeg } \\
\text { dataset: } 88 \mathrm{NB} \\
\text { samples, Kocak } \\
\text { dataset: } 476 \\
\text { NB samples }\end{array}$ & $\mathrm{BE}(2)-\mathrm{C}$ & NCYM, N-myc, NonO & - & LncUSMycN up-regulates NCYM expression. & - & $(115)$ \\
\hline & $\begin{array}{l}47 \text { primary NB } \\
\text { samples, } \\
\text { Versteeg } \\
\text { dataset: } 88 \text { NB } \\
\text { tissues, Kocak } \\
\text { dataset: } 476 \\
\text { NB tissues }\end{array}$ & $\begin{array}{l}\text { IMR32, } \\
\text { BE2C, SK-N-DZ, } \\
\text { CHP134, Kelly, SK-N-FI, } \\
\text { SK-N-AS, NB69, SY5Y, } \\
\text { SHEP, LAN-1 }\end{array}$ & NonO, N-Myc & - & $\begin{array}{l}\text { IncUSMycN increase up-regulates N-Myc RNA } \\
\text { and NB cell proliferation. }\end{array}$ & Poor OS & $(86)$ \\
\hline HOXD-AS1 & $\begin{array}{l}\text { GSE3446 } \\
\text { dataset: } 102 \\
\text { NB patients }\end{array}$ & SH-SY5Y & $\begin{array}{l}\text { MAGEA9B, SNN, } \\
\text { TMEM86A, VIPR1, } \\
\text { CREM, TSPAN2, } \\
\text { CNR1, CREBL1, } \\
\text { PTGS1, ADAMTS3, } \\
\text { AMDMD2, ANG, } \\
\text { ASNA1/retinoic acid }\end{array}$ & $\begin{array}{l}\text { PI3K/AKt, } \\
\text { JAK/STAT }\end{array}$ & $\begin{array}{l}\text { Following RA treatment, HOXD-AS1 diminishes } \\
\text { the expression of genes involved in NB } \\
\text { progression, angiogenesis, and inflammation. }\end{array}$ & - & (116) \\
\hline CAl2 & $\begin{array}{l}62 \text { primary NB } \\
\text { samples and } 25 \\
\text { healthy controls }\end{array}$ & FS15, NMB7 & $\mathrm{P} 16, \mathrm{ARF}$ & - & $\begin{array}{l}\text { CAl2 expression is significantly higher in } \\
\text { advanced-stage NB. }\end{array}$ & Poor OS & $(87)$ \\
\hline Paupar & - & $\mathrm{N} 2 \mathrm{~A}$ & $\begin{array}{l}\text { KAP1, PAX6, RCOR3, } \\
\text { PPAN, CHE-1, ERH }\end{array}$ & - & $\begin{array}{l}\text { Paupar regulates expression of some target } \\
\text { genes involved in the regulation of neuronal } \\
\text { function and cell cycle. }\end{array}$ & - & $(117)$ \\
\hline
\end{tabular}


TABLE 4 | Continued

\begin{tabular}{|c|c|c|c|c|c|c|c|}
\hline IncRNA & Specimens & Cell lines & Targets/regulators & $\begin{array}{l}\text { Signaling } \\
\text { pathway }\end{array}$ & Function & $\begin{array}{l}\text { Effect of } \\
\text { IncRNA up- } \\
\text { regulation } \\
\text { on patient's } \\
\text { prognosis }\end{array}$ & Ref \\
\hline & - & $\mathrm{N} 2 \mathrm{~A}$ & $\begin{array}{l}\text { PAX6, E2f2, E2f7, } \\
\text { Cdc6, Cdkn2c, Kdm7a, } \\
\text { Sox1, Sox2, Hoxa1, } \\
\text { Hes1 }\end{array}$ & - & $\begin{array}{l}\text { Paupar silencing disrupts the cell cycle } \\
\text { transition and stimulates neuron differentiation. }\end{array}$ & - & $(118)$ \\
\hline NORAD & $\begin{array}{l}38 \text { pairs of NB } \\
\text { and normal } \\
\text { tissues }\end{array}$ & $\begin{array}{l}\text { SK-N-SH, IMR-32, } \\
\text { HUVEC }\end{array}$ & MiR-144-3p, HDAC8 & - & $\begin{array}{l}\text { NORAD enhances the proliferation, tumor } \\
\text { growth, metastasis, and doxorubicin } \\
\text { resistance, though it restricts apoptosis and } \\
\text { autophagy. }\end{array}$ & - & (119) \\
\hline CASC11 & $\begin{array}{l}42 \text { neonatal NB } \\
\text { and } 42 \text { normal } \\
\text { tissues }\end{array}$ & $\begin{array}{l}\text { SK-N-AS and NB-1, } \\
\text { hTERT-RPE1 }\end{array}$ & $\begin{array}{l}\text { miR-676-3p, NOL4L, } \\
\text { AGO2 }\end{array}$ & - & $\begin{array}{l}\text { CASC11 depletion represses cell proliferation } \\
\text { and invasiveness. }\end{array}$ & Poor survival & $(120)$ \\
\hline DUXAP8 & $\begin{array}{l}45 \text { NB patients, } \\
\text { at } 1+2+4 S \\
\text { stage }(n=18) \\
\text { and } 3+4 \text { stage } \\
(n=27)\end{array}$ & $\begin{array}{l}\text { SK-N-SH, IMR-32, } \\
\text { HUVEC, HEK293T }\end{array}$ & miR-29, NOL4L & $\begin{array}{l}\text { Wnt } / \beta- \\
\text { catenin }\end{array}$ & $\begin{array}{l}\text { DUXAP8 expression is positively related to the } \\
\text { stage of NB tumors and is negatively } \\
\text { associated with the survival rate of NB patients. } \\
\text { DUXAP8 knock-down reduces the proliferation, } \\
\text { colony formation, cycle, and motility of NB } \\
\text { cells. }\end{array}$ & Lower OS & $(121)$ \\
\hline SNHG4 & $\begin{array}{l}30 \text { primary NB } \\
\text { and ANTs }\end{array}$ & $\begin{array}{l}\text { SH-SY5Y, CHP-212, SK- } \\
\text { N-FI, IMR-32, HEK293T }\end{array}$ & miR-377-3p & - & $\begin{array}{l}\text { LncRNA SNHG4 escalates NB proliferation, } \\
\text { migration, EMT, and invasion and reduces the } \\
\text { apoptosis rate. }\end{array}$ & $\begin{array}{l}\text { Lower } \\
\text { survival rate }\end{array}$ & (122) \\
\hline IncNB & 476 NB patients & & $\mathrm{BMX}$ & & $\begin{array}{l}\text { The super-enhancer driven long non-coding } \\
\text { RNA IncNB promotes neuroblastoma } \\
\text { tumorigenesis. }\end{array}$ & $\begin{array}{l}\text { Poor } \\
\text { prognosis }\end{array}$ & \\
\hline NHEG1 & $\begin{array}{l}\text { GSE62564 } \\
\text { dataset: } 498 \\
\text { patients, } 42 \\
\text { primary NB } \\
\text { cases and } 21 \\
\text { normal dorsal } \\
\text { ganglia }\end{array}$ & $\begin{array}{l}\text { MCF-10A, SK-N-BE(2), } \\
\text { IMR32, BE(2)-C, NB- } \\
\text { 1643, NB-1691, } \\
\text { SH-SY5Y, SK-N-SH, SK- } \\
\text { N-AS, HCT116 }\end{array}$ & $\begin{array}{l}\text { DDX5, } \beta \text {-catenin/LEF1, } \\
\text { TCF7L2 }\end{array}$ & $\begin{array}{l}\text { Wnt } / \beta- \\
\text { catenin }\end{array}$ & $\begin{array}{l}\text { NHEG1 depletion accelerates differentiation and } \\
\text { inhibits the proliferation and aggressiveness of } \\
\text { NB cells. }\end{array}$ & $\begin{array}{l}\text { Lower OS } \\
\text { and EFS }\end{array}$ & $(123)$ \\
\hline XIST & $\begin{array}{l}30 \mathrm{NB} \text { and } \\
\text { ANTs }\end{array}$ & $\begin{array}{l}\text { SK-N-BE(2), HEK293, } \\
\text { GI-LI-N }\end{array}$ & HK2, miR-653-5p & - & $\begin{array}{l}\text { XIST knock-down curtails tumorigenesis by } \\
\text { suppressing proliferation and invasion. It also } \\
\text { increases the radiosensitivity by diminishing } \\
\text { colony constuction and glycolysis. }\end{array}$ & - & $(124)$ \\
\hline
\end{tabular}

role of a number of SNPs within lncRNAs such as LINC00673, H19, MEG3 and HOTAIR has been evaluated in this regard (137-140). Moreover, the rs4938723 within miR-34b/c has been associated with risk of this kind of cancer (141). Notably, some studies have appraised these associations in certain subgroups of patients. For instance, the association between rs4938723 TC and CC genotypes is prominent in all age-based subgroups, both sexes, retroperitoneal tumors as well as tumors originated from other sites, and all clinical stages (141). Such detailed analyses have not been done for all assessed SNPs. Table 8 summarizes the results of studies which assessed contribution of SNPs within ncRNAs in conferring the risk of neuroblastoma.

\section{DISCUSSION}

Recent studies have demonstrated abnormal expression of lncRNAs, miRNAs and circRNAs in neuroblastoma. Besides, some SNPs within lncRNAs and miRNAs confer risk of neuroblastoma. In vitro studies have shown the functional interactions between a number of these ncRNAs and MYCN, the oncogene that has essential roles in the pathogenesis of this type of cancer. Moreover, certain miRNAs have been shown to target tyrosine kinase receptors. For instance, hsa-miR-376c is predicted to target ALK tyrosine kinase receptor. Notably, this miRNA has been up-regulated in neuroblastoma samples of long-survivors (146). Expressions of a number of other ncRNAs have been shown to stratify neuroblastoma patients based on their risk of recurrence and clinical outcome.

The observed dysregulation of ncRNAs in neuroblastoma can be explained by their association with the frequent chromosomal abnormalities in this kind of cancer. Amplification of genomic loci corresponding to these transcripts is a possible route for their up-regulation (86). Moreover, epigenetic factors participate in the regulation of ncRNAs expression in neuroblastoma, as several lines of evidence points to the role of retinoic acid and its derivatives in the reversal of such dysregulation. Consistent with these observations, ATRA has been lately shown to induce differentiation of a number of neuroblastoma cell lines or activate apoptosis in these cells (147). 
TABLE 5 | Down-regulated IncRNAs in neuroblastoma (NB, Neuroblastoma; OS, overall survival; EFS, event-free survival).

\begin{tabular}{|c|c|c|c|c|c|c|c|}
\hline IncRNA & Specimens & Cell line & $\begin{array}{l}\text { Targets/ } \\
\text { regulators }\end{array}$ & $\begin{array}{l}\text { Signaling } \\
\text { pathway }\end{array}$ & Function & $\begin{array}{l}\text { Effect of } \\
\text { IncRNA down- } \\
\text { regulation on } \\
\text { patient's } \\
\text { prognosis }\end{array}$ & Reference \\
\hline NR_120420 & - & SH-SY5Y & $\begin{array}{l}\text { P65, ERK, } \\
\text { AKT }\end{array}$ & $N F-\kappa B$ & $\begin{array}{l}\text { The knock-down of NR_120420 enhances cell } \\
\text { viability but reduces the apoptosis. }\end{array}$ & - & (125) \\
\hline CASC15 & $\begin{array}{l}220 \text { high-risk NB } \\
\text { samples }\end{array}$ & $\begin{array}{l}\text { SK-N-BE2, SK- } \\
\text { N-SH }\end{array}$ & $\begin{array}{l}\text { NEUROD1, } \\
\text { NEDD9, } \\
\text { NEUROG2 }\end{array}$ & - & $\begin{array}{l}\text { CASC15 depletion improves proliferation and invasive } \\
\text { capabilities and shifts the NB gene expression away } \\
\text { from the differentiated neural phenotype. }\end{array}$ & Lower OS & (126) \\
\hline NBAT1 & $\begin{array}{l}\text { Two cohorts: one } \\
\text { with } 59 \text { and the } \\
\text { other with } 498 \mathrm{NB} \\
\text { patients }\end{array}$ & $\begin{array}{l}\text { SHSY-5Y, SK- } \\
\text { N-AS, IMR32, } \\
\text { SK-N-BE2, } \\
\text { hESCS, } \\
\text { HEK293T }\end{array}$ & $\begin{array}{l}\text { SOX9, } \\
\text { CHD7, } \\
\text { USP36 }\end{array}$ & - & $\begin{array}{l}\text { These IncRNAs regulate SOX9 expression through } \\
\text { regulation of CHD7 stability. Loss of this synergy } \\
\text { between these IncRNAs enhances proliferation, } \\
\text { migration, invasion, colony formation of NB cells. }\end{array}$ & $\begin{array}{l}\text { Poor OS and } \\
\text { EFS }\end{array}$ & (127) \\
\hline $\begin{array}{l}\text { FOXD3- } \\
\text { AS1 }\end{array}$ & $\begin{array}{l}42 \text { NB tumor } \\
\text { samples, } \\
\text { GSE16476 dataset: } \\
88 \text { cases of NB }\end{array}$ & $\begin{array}{l}\text { NB-1643, SK- } \\
\text { N-BE(2), NB- } \\
\text { 1691, IMR32, } \\
\text { BE(2)-C, SK-N- } \\
\text { AS, SH-SY5Y, } \\
\text { SK-N-SH }\end{array}$ & $\begin{array}{l}\text { PARP1, } \\
\text { CTCF }\end{array}$ & - & $\begin{array}{l}\text { Over-expression of FOXD3-AS1 promotes neuronal } \\
\text { differentiation and reduces aggressive behavior of } \\
\text { these cells. }\end{array}$ & Poor survival & $(128)$ \\
\hline MEG3 & $\begin{array}{l}\text { Tumor and para- } \\
\text { tumor tissue } \\
\text { samples }(n=6)\end{array}$ & $\mathrm{BE}(2)-\mathrm{C}$ & $\begin{array}{l}\text { PMAIP1, } \\
\text { BID, HIF-1 } \alpha\end{array}$ & - & $\begin{array}{l}\text { MEG3 overexpression reduces proliferation and } \\
\text { elevates apoptosis rate. }\end{array}$ & - & $(114)$ \\
\hline $\begin{array}{l}\text { Linc- } \\
\text { NeD125 }\end{array}$ & - & $\begin{array}{l}\text { BE(2)-C, } \\
\text { D283Med, } \\
\text { NB4, HL-60 }\end{array}$ & BCL-2 & - & $\begin{array}{l}\text { Linc-NeD125 is the host gene of miR-125b-1. Its } \\
\text { down-regulation reduces cell proliferation and } \\
\text { activates the antiapoptotic factor BCL-2. }\end{array}$ & - & $(129)$ \\
\hline MYCNOS & - & Lan6 & $\begin{array}{l}\text { MYCN, } \\
\text { MAP4, } \\
\text { G3BP1, } \\
\text { FKBP3 }\end{array}$ & - & $\begin{array}{l}\text { MYCNOS RNA localizes to the MYCN promoter and } \\
\text { reduces its expression. }\end{array}$ & - & $(130)$ \\
\hline CASC15-S & $\begin{array}{l}\mathrm{NCl} \text { TARGET } \\
\text { project: } 108 \mathrm{NB} \\
\text { patients }\end{array}$ & $\begin{array}{l}\text { SK-N-BE2, SK- } \\
\text { N-SH, } \\
\text { HEK293T }\end{array}$ & $\begin{array}{l}\text { ALCAM, } \\
\text { NEUROD1, } \\
\text { NEDD9, } \\
\text { NEUROG2 }\end{array}$ & - & $\begin{array}{l}\text { Attenuating CASC15-S elevates cellular proliferation, } \\
\text { proliferation, invasion, and migratory capacity. } \\
\text { CASC15-S regulates genes involved in neural crest } \\
\text { development. }\end{array}$ & Poor OS & (126) \\
\hline NBAT-1 & $\begin{array}{l}15 \text { NB snap-frozen } \\
\text { tumors, } 108 \text { patients } \\
\text { and RNA-seq data } \\
\text { of } 498 \text { patients }\end{array}$ & $\begin{array}{l}\text { SK-N-FI, SH- } \\
\text { SY5Y, SK-N- } \\
\text { AS, SK-N-BE(2) }\end{array}$ & $\begin{array}{l}\text { NRSF, } \\
\text { REST, } \\
\text { SOX9, } \\
\text { VCAN, } \\
\text { EZH2 }\end{array}$ & - & $\begin{array}{l}\text { NBAT-1 down-regulation boosts cellular proliferation } \\
\text { and invasion and inhibits neuronal differentiation. }\end{array}$ & Poor survival & (85) \\
\hline CASC7 & 48 NB patients & LAN-2 & $\begin{array}{l}\text { miR-10a, } \\
\text { PTEN }\end{array}$ & - & $\begin{array}{l}\text { CASC7 overexpression decreases the proliferation of } \\
\text { NB cells. }\end{array}$ & - & (131) \\
\hline KCNQ1OT1 & $\begin{array}{l}\text { Xena datahub: } 128 \\
\text { NB tissues }\end{array}$ & $\begin{array}{l}\text { SH-SY5Y, } \\
\text { IMR32, } \\
\text { HEK293T }\end{array}$ & $\begin{array}{l}\operatorname{miR}-296- \\
5 p, \text { Bax }\end{array}$ & - & $\begin{array}{l}\text { KCNQ1OT1 acts as a sponge for miR-296-5p. miR- } \\
296-5 p \text { inhibits Bax protein and cell apoptosis. }\end{array}$ & - & (132) \\
\hline NEAT1 & $30 \mathrm{NB}$ tissues & $\begin{array}{l}\text { SKN-SH, SH- } \\
\text { SY5Y, IMR-32, } \\
\text { SH-N-AS }\end{array}$ & $\begin{array}{l}\text { miR-183- } \\
5 p, \text { FOXP1 }\end{array}$ & ERK/AKT & $\begin{array}{l}\text { NEAT1 up-regulation lowers cell proliferation, } \\
\text { migration, and invasion rates. }\end{array}$ & - & (133) \\
\hline
\end{tabular}

As a number of ncRNAs regulate tumorigenic process downstream of MYCN, dysregulation of these transcripts might represent an alternative mechanism of MYCN upregulation/amplification in neuroblastoma. In vivo studies have demonstrated the efficacy of miRNA antagonism in suppression of proliferation of $M Y C N$-amplified neuroblastoma cells in animal models (68). However, these results have not been replicated in clinical settings. Administration of miRNA mimics in clinical settings has encountered some problems most of the being related with the distribution of these transcripts in the body and enrichment in the target organs. Encapsulation of these small transcripts in nanoparticle vesicles is expected to enhance their stability and their presence in the circulation, permitting further time for their amassment in tumor tissues (148).

Multidrug resistance is a problem in the treatment of patients with neuroblastoma. Such phenotype has been associated with a number of genetic abnormalities such as over-expression of MYCN oncogene, hyper-activation of tyrosine kinase receptors (BDNF-TrkB) or reduced expression and activity of tumor suppressor genes including p53 (148). Therefore, ncRNAs that modulate expression of these elements or function in the downstream of these molecules can also be involved in the multidrug resistance of these cells. Therefore, modulation of expression of these transcripts represents a novel modality to combat multidrug resistance in neuroblastoma. 
TABLE 6 | Prognostic value of IncRNAs in neuroblastoma (NB, neuroblastoma; OS, overall survival; EFS, event-free survival).

\begin{tabular}{|c|c|c|c|}
\hline Sample number & Kaplan-Meier analysis & Multivariate cox regression & Reference \\
\hline $\begin{array}{l}\text { Two groups of } 35 \text { patients, each expressing } \\
\text { low and high levels of DLX6AS1 }\end{array}$ & $\begin{array}{l}\text { High DLX6-AS1 expression correlates with } \\
\text { a low OS rate of NB patients. }\end{array}$ & - & (90) \\
\hline $\begin{array}{l}\text { EQC-RPM-seqcnb1 dataset: } 246 \text { low and } 247 \\
\text { high expression groups of IncNB1 }\end{array}$ & $\begin{array}{l}\text { High levels of IncNB1 correlate with poor } \\
\text { prognosis. }\end{array}$ & - & (92) \\
\hline $\begin{array}{l}\text { Genomics Analysis and Visualization Platform } \\
\text { for NB dataset: Two groups of high }(=21) \text { and } \\
\text { low (=67) for LINC01296 expression }\end{array}$ & $\begin{array}{l}\text { High LINC01296 expression is associated } \\
\text { with poor outcome. }\end{array}$ & - & $(94)$ \\
\hline $\begin{array}{l}\text { GSE62564 dataset: two groups of low and } \\
\text { high expression for SNHG16 expression, each } \\
\text { containing } 249 \text { patients }\end{array}$ & $\begin{array}{l}\text { High levels of SNHG16 expression } \\
\text { correlates with lower EFS and OS. }\end{array}$ & - & (95) \\
\hline $\begin{array}{l}\text { High }(=34) \text { and low }(=10) \text { expressing groups of } \\
\text { RMRP IncRNA }\end{array}$ & $\begin{array}{l}\text { Higher RMRP expression relates to poor } \\
\text { prognosis and survival. }\end{array}$ & - & $(104)$ \\
\hline $\begin{array}{l}\text { GAU1 expression in two groups from TCGA } \\
\text { dataset: high }(=44) \text { and low }(=44) \\
\text { GALNT8 expression in two groups from TCGA } \\
\text { dataset: high }(=13) \text { and low }(=75)\end{array}$ & $\begin{array}{l}\text { High GAU1 expression correlates with } \\
\text { lower OS. } \\
\text { Higher GALNT8 levels correlate with poor } \\
\text { OS. }\end{array}$ & 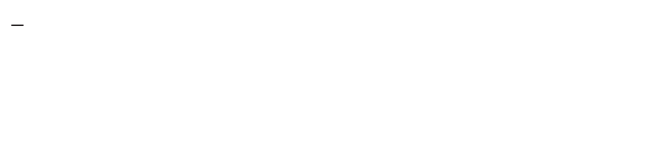 & $(107)$ \\
\hline $\begin{array}{l}\text { CASC15 expression: } \\
\text { Cohort a: high (=29) and low (=30) expression } \\
\text { groups } \\
\text { Cohort b: high and low groups, each } \\
\text { containing } 249 \text { patients }\end{array}$ & $\begin{array}{l}\text { Lower levels of CASC15 expression } \\
\text { correlate with lower OS and EFS. }\end{array}$ & Both CASC15-003 and CASC15-004 predict OS and EFS. & $(127)$ \\
\hline $\begin{array}{l}\text { GSE16476 dataset: } 88 \text { NB cases, expressing } \\
\text { high (=22) and low (=66) levels of FOXD3-AS1 } \\
42 \text { NB patients expressing high }(=19) \text { and low } \\
\text { (23) levels of FOXD3-AS1 }\end{array}$ & $\begin{array}{l}\text { Lower expression levels of FOXD3-AS1 } \\
\text { correlate with lower OS. }\end{array}$ & FOXD3-AS1 is a possible independent prognostic factor. & $(128)$ \\
\hline $\begin{array}{l}\text { pancEts- } 1 \text { expression: } \\
42 \text { NB patients }(\mathrm{low}=23 \text {, high=19) and } 88 \text { NB } \\
\text { cases (low=50, high=38) from GSE16476 } \\
\text { dataset }\end{array}$ & $\begin{array}{l}\text { Higher levels of pancEts- } 1 \text { negatively } \\
\text { correlate with survival rate. }\end{array}$ & $\begin{array}{l}\text { Patients' age, MYCN amplification, INSS stage, pancEts-1 } \\
\text { expression, and hnRNPK expression, but not gender, are } \\
\text { independent prognostic factors for poor outcome. }\end{array}$ & $(109)$ \\
\hline $\begin{array}{l}\text { SNHG1 expression in GSE62564 dataset: } 246 \\
\text { low and } 247 \text { high, GSE16476 dataset: } 44 \text { low } \\
\text { and } 44 \text { high }\end{array}$ & $\begin{array}{l}\text { Higher expression levels of SNHG1 } \\
\text { negatively correlate with OS and EFS. }\end{array}$ & $\begin{array}{l}\text { SNHG1 high expression is a significant low hazard rate } \\
\text { indicator for both OS and EFS. }\end{array}$ & $(106)$ \\
\hline $\begin{array}{l}\text { CAI } 2 \text { expression in NB patients: high }=19 \\
\text { low }=43\end{array}$ & $\begin{array}{l}\text { CAI } 2 \text { expression negatively correlates with } \\
\text { OS and EFS. }\end{array}$ & 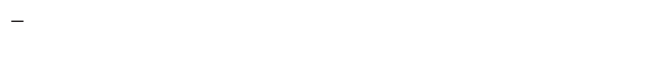 & (87) \\
\hline $\begin{array}{l}\text { NBAT-1 expression in } 2 \text { cohorts: 1) } 50 \text { high } \\
\text { and } 43 \text { low, 2) } 314 \text { high and } 184 \text { low }\end{array}$ & $\begin{array}{l}\text { NBAT expression significantly correlates } \\
\text { with OS and EFS. }\end{array}$ & $\begin{array}{l}\text { NBAT-1 is an independent prognostic marker in predicting } \\
\text { EFS. }\end{array}$ & $(85)$ \\
\hline $\begin{array}{l}\text { Inc USMycN expression: Versteeg dataset: } 79 \\
\text { low and } 9 \text { high, Kocak dataset: } 429 \text { low and } \\
47 \text { high }\end{array}$ & $\begin{array}{l}\text { High levels of IncUSMycN expression have } \\
\text { been linked with poor survival. }\end{array}$ & $\begin{array}{l}\text { High levels of IncUSMycN and NonO expression in are } \\
\text { linked with poor OS, independent of disease stage, age at } \\
\text { diagnosis, and MYCN amplification. }\end{array}$ & (86) \\
\hline $\begin{array}{l}\text { CASC15-S expression in NB patients: } \\
\text { low }=163 \text {, high } 87\end{array}$ & $\begin{array}{l}\text { Higher levels of CASC15-S significantly } \\
\text { correlate with longer OS in NB patients. }\end{array}$ & - & $(126)$ \\
\hline CASC15-S expression: 163 low, 87 high & $\begin{array}{l}\text { CASC15-S expression in NB patients } \\
\text { significantly correlates with OS. }\end{array}$ & $\begin{array}{l}\text { CASC15-S expression is correlated with more aggressive } \\
\text { features and lower OS. }\end{array}$ & $(126)$ \\
\hline $\begin{array}{l}\text { CASC11 expression in NB patients: } 21 \text { high } \\
\text { and } 21 \text { low }\end{array}$ & $\begin{array}{l}\text { CASC11 expression negatively correlates } \\
\text { with the survival rate. }\end{array}$ & - & $(120)$ \\
\hline $\begin{array}{l}\text { DUXAP8 expression in two groups: group 1: } 1 \\
+2+4 \text { S stage }(n=18) \text { and group } 2: 3+4 \\
\text { stage }(n=27)\end{array}$ & $\begin{array}{l}\text { The survival rate is low in high expression } \\
\text { of the DUXAP8 group compared with lower } \\
\text { expression of the DUXAP8 group. }\end{array}$ & - & $(121)$ \\
\hline $\begin{array}{l}\text { SNHG7 expression level in NB patients: } 25 \\
\text { high and } 20 \text { low }\end{array}$ & $\begin{array}{l}\text { SNHG7 expression levels negatively } \\
\text { correlate with the OS rate. }\end{array}$ & - & $(103)$ \\
\hline $\begin{array}{l}\text { NHEG1 expression: GSE62564 dataset: } 498 \\
\text { patients (432=low, 66=high), } 42 \text { primary NB } \\
\text { cases and } 21 \text { normal dorsal ganglia }\end{array}$ & $\begin{array}{l}\text { NHEG1 expression negatively correlates } \\
\text { with OS and EFS rates. }\end{array}$ & $\begin{array}{l}\text { NHEG1 expression has a significant prognostic value for NB } \\
\text { patients. }\end{array}$ & $(123)$ \\
\hline $\begin{array}{l}\text { SNHG16 expression in NB patients: high }=22 \text {, } \\
\text { low }=23\end{array}$ & $\begin{array}{l}\text { SNHG expression levels negatively } \\
\text { correlates with OS. }\end{array}$ & - & (99) \\
\hline
\end{tabular}

Expression profile of ncRNAs has been correlated with patients' survival. The underlying mechanism of this observation has been clarified in some cases. For instance, hsamiR-383, hsa-miR-548d-5p, hsa-miR-939 and hsa-miR-877* miRNAs which have been down-regulated in neuroblastoma samples from long-survivors (146) target a number of genes being involved in the neuronal differentiation (149).
Taken together, the above-mentioned evidence suggests the crucial roles of ncRNAs in the regulation of important aspects of cell survival, proliferation and differentiation and their participation in the pathogenesis of neuroblastoma. Their potential as therapeutic targets for this type of cancer should be more explored in the future studies. The main limitation of studies which assessed expression of ncRNAs in 
TABLE 7 | List of circRNAs dysregulated in neuroblastoma.

\begin{tabular}{|c|c|c|c|c|c|c|c|}
\hline circRNA & $\begin{array}{l}\text { Pattern of } \\
\text { expression }\end{array}$ & Samples & Cell line & $\begin{array}{l}\text { Targets/ } \\
\text { regulators }\end{array}$ & Function & $\begin{array}{l}\text { Patient's } \\
\text { prognosis }\end{array}$ & Reference \\
\hline circDGKB & $\uparrow$ & $\begin{array}{l}30 \text { NB tissues and } \\
10 \text { normal dorsal } \\
\text { root ganglia as } \\
\text { controls }\end{array}$ & $\begin{array}{l}\text { SK-N-SH, SH- } \\
\text { SY5Y }\end{array}$ & $\begin{array}{l}\text { miR-873, } \\
\text { GLI1, } \\
\text { ZEB1 }\end{array}$ & $\begin{array}{l}\text { circDGKB up-regulation improves the proliferation, } \\
\text { migration, invasion, and } \\
\text { tumorigenesis, though it reduces cell apoptosis. }\end{array}$ & Lower OS & (135) \\
\hline $\begin{array}{l}\text { circ- } \\
\text { CUX1 }\end{array}$ & $\uparrow$ & $\begin{array}{l}54 \text { NB patients, } \\
\text { GSE16476 dataset: } \\
88 \text { NB patients, } \\
\text { oncogenomic } \\
\text { database: } 117 \text { NB } \\
\text { and } 3 \text { normal tissues }\end{array}$ & $\begin{array}{l}\text { MCF 10A, HeLa, } \\
\text { SH-SY5Y, IMR32, } \\
\text { SK-N-AS, BE(2)-C, } \\
\text { SK-NMC, LoVo, } \\
\text { PC-3, HEK293, } \\
\text { HEK293T }\end{array}$ & $\begin{array}{l}\text { EWSR1, } \\
\text { MAZ, } \\
\text { CUX1 }\end{array}$ & $\begin{array}{l}\text { circ-CUX1 knock-down inhibits aerobic glycolysis, } \\
\text { proliferation, progression, and aggressiveness of NB. } \\
\text { circ-CUX1 binds to EWSR1 to enable its contact with } \\
\text { MAZ, leading to transactivation of MAZ and } \\
\text { transcriptional modification of CUX1 and other genes } \\
\text { linked with cancer progression. }\end{array}$ & $\begin{array}{l}\text { Lower } \\
\text { survival } \\
\text { rate }\end{array}$ & (136) \\
\hline
\end{tabular}

TABLE 8 | Polymorphisms within non-coding RNAs and risk of neuroblastoma.

\begin{tabular}{|c|c|c|c|c|c|c|c|}
\hline $\begin{array}{l}\text { IncRNA/ } \\
\text { miRNA }\end{array}$ & $\begin{array}{c}\text { Number of } \\
\text { clinical } \\
\text { samples }\end{array}$ & SNP ID & $\begin{array}{l}\text { Nucleotide } \\
\text { change }\end{array}$ & OR (95\%Cl) & p-value & Description & Reference \\
\hline LINC00673 & $\begin{array}{l}700 \text { cases and } \\
1516 \text { controls }\end{array}$ & rs11655237 & $\mathrm{C}>\mathrm{T}$ & $1.58(1.06-2.35)$ & 0.024 & $\begin{array}{l}\text { Patients with the T allele are considerably more prone to } \\
\text { develop NB. A substantial association exists between } \\
\text { rs11655237 CT/TT and NB risk in subgroups of males, } \\
\text { adrenal gland tumors, and patients with stage IV disease. }\end{array}$ & $(137)$ \\
\hline $\mathrm{H} 19$ & $\begin{array}{l}393 \mathrm{NB} \\
\text { patients and } \\
812 \text { healthy } \\
\text { controls }\end{array}$ & $\begin{array}{l}\text { rs2839698 } \\
\text { rs3024270 } \\
\text { rs217727 }\end{array}$ & $\begin{array}{l}G>A \\
C>G \\
G>A\end{array}$ & $\begin{array}{l}- \\
1.61(1.04-2.50) \\
-\end{array}$ & $\begin{array}{l}- \\
0.032 \\
-\end{array}$ & $\begin{array}{l}\text { Separated and combined analyses indicated no } \\
\text { associations between these polymorphisms and NB } \\
\text { susceptibility. Only female children with rs3024270 GG } \\
\text { genotypes had a raised NB risk. }\end{array}$ & (138) \\
\hline MEG3 & $\begin{array}{l}392 \text { NB } \\
\text { children and } \\
783 \text { controls }\end{array}$ & $\begin{array}{l}\text { rs7158663 } \\
\text { rs4081134 }\end{array}$ & $\begin{array}{l}G>A \\
G>A\end{array}$ & $\begin{array}{l}- \\
\text { NB } \\
\text { developments: } \\
1.36 \text { (1.01- } \\
\text { 1.84), clinical } \\
\text { stage III+IV: } \\
1.47 \text { (1.08-1.99) }\end{array}$ & $\begin{array}{l}- \\
0.042 \text { and } \\
0.014 \\
\text { respectively }\end{array}$ & $\begin{array}{l}\text { Patients with rs } 4081134 \text { AG/AA genotypes were } \\
\text { significantly prone to develop NB among subgroups with } \\
\text { age }>18 \text { months and stage III+IV. Carriers of these two } \\
\text { polymorphisms were more prone to NB. These } \\
\text { associations were found in children more than } 18 \text { months } \\
\text { and with clinical stages of III+IV. }\end{array}$ & $(142)$ \\
\hline CAC15-S & $\begin{array}{l}250 \text { primary } \\
\text { NB, } 20 \text { NB cell } \\
\text { lines }\end{array}$ & rs9295534 & $\mathrm{T}>\mathrm{A}$ & $1.63(1.4-1.89)$ & $3.51 \times 10^{-12}$ & $\begin{array}{l}\text { This polymorphism is located upstream of CASC15-S } \\
\text { and spans regulatory chromatin and dense transcription } \\
\text { factor binding site. This genomic area has an enhancer- } \\
\text { like activity that is disturbed by NB risk allele. }\end{array}$ & $(126)$ \\
\hline HOTAIR & $\begin{array}{l}393 \text { NB and } \\
812 \text { healthy } \\
\text { controls }\end{array}$ & $\begin{array}{l}\text { rs12826786 } \\
\text { rs874945 } \\
\text { rs1899663 }\end{array}$ & $\begin{array}{l}C>T \\
C>T \\
C>A\end{array}$ & $\begin{array}{l}1.98(1.14-3.42) \\
1.91(1.10-3.32) \\
1.87(1.05-3.32)\end{array}$ & $\begin{array}{l}0.015 \\
0.022 \\
0.033\end{array}$ & $\begin{array}{l}\text { These polymorphisms are markedly associated with } \\
\text { increased NB risk. In stratification analyses, these } \\
\text { associations are more dominant in females and among } \\
\text { patients with tumors in the retroperitoneal or mediastinal } \\
\text { tumors. }\end{array}$ & $(140)$ \\
\hline LINC00673 & $\begin{array}{l}393 \text { NB and } \\
812 \text { healthy } \\
\text { controls }\end{array}$ & rs11655237 & $\mathrm{C}>\mathrm{T}$ & $\begin{array}{l}\text { NB risk: } 1.51 \\
(1.06-2.14) \\
\text { stage } \mathrm{IV} \\
\text { disease: } 1.60 \\
(1.12-2.30)\end{array}$ & $\begin{array}{l}0.021 \text { and } \\
0.011 \\
\text { respectively }\end{array}$ & $\begin{array}{l}\text { Carriers of rs } 11655237 \mathrm{~T} \text { allele are prone to NB. } \\
\text { Associations were found in patients with adrenal gland } \\
\text { tumors and stage IV disease. }\end{array}$ & $(143)$ \\
\hline uc003opf.1 & $\begin{array}{l}275 \text { patients } \\
\text { and } 531 \\
\text { controls }\end{array}$ & rs11752942 & $A>G$ & $0.74(055-0.99)$ & 0.045 & $\begin{array}{l}\text { rs } 11752942 \text { G allele is negatively related to NB risk and is } \\
\text { more prominent in females, subjects with tumors in the } \\
\text { mediastinum or early-stage. Besides, rs } 11752942 \mathrm{G} \text { is } \\
\text { associated with deceased levels of LRFN2 transcripts. }\end{array}$ & $(144)$ \\
\hline $\begin{array}{l}\text { CASC15 and } \\
\text { NBAT1 }\end{array}$ & $\begin{array}{l}36 \text { NB patients } \\
\text { and NB cell lines }\end{array}$ & rs6939340 & $A>G$ & - & - & $\begin{array}{l}\text { This polymorphism results in lowered expression of } \\
\text { CASC15 and NBAT1. }\end{array}$ & $(127)$ \\
\hline NBAT1 & $\begin{array}{l}51 \text { high-risk } \\
\text { primary tumors } \\
\text { and NB cell lines }\end{array}$ & rs6939340 & $A>G$ & - & $P<0.05$ & $\begin{array}{l}\text { Lowered NBAT-1 expression in high-risk tumors relates } \\
\text { to rs6939340. }\end{array}$ & (85) \\
\hline $\begin{array}{l}\text { Lnc-LAMC2- } \\
1: 1\end{array}$ & $\begin{array}{l}393 \text { NB and } 812 \\
\text { healthy cases }\end{array}$ & rs2147578 & $\mathrm{C}>\mathrm{G}$ & $1.33(1.01-1.75)$ & 0.045 & $\begin{array}{l}\text { rs2147578 rises NB susceptibility. Children under } 18 \\
\text { months and females have increased NB risk. }\end{array}$ & $(145)$ \\
\hline miR-34b/c & $\begin{array}{l}162 \text { NB and } \\
270 \text { healthy } \\
\text { controls }\end{array}$ & rs4938723 & $\mathrm{T}>\mathrm{C}$ & $0.49(0.33-0.73)$ & 0.0005 & $\begin{array}{l}\text { rs4938723 diminishes NB risk. The stratified analysis } \\
\text { demonstrates that rs } 4938723 \text { TC/CC carriers are less prone } \\
\text { to NB. Such association was found in both age subgroups, } \\
\text { both sexes as well as all tumor sites and stages. }\end{array}$ & $(141)$ \\
\hline
\end{tabular}


neuroblastoma is lack of longitudinal assessment of expression of these transcripts to unravel temporal changes during the course of disease. Conduction of this type of studies would facilitate approval of the diagnostic and prognostic power of ncRNAs.

\section{REFERENCES}

1. Grau E, Oltra S, Orellana C, Hernández-Martí M, Castel V. There is no evidence that the SDHB gene is involved in neuroblastoma development. Oncol Res Featuring Preclinical Clin Cancer Ther (2005) 15(7-8):393-8. doi: 10.3727/096504005776449671

2. Kushner BH, Cheung N-KV. Neuroblastoma-from genetic profiles to clinical challenge. New Engl J Med (2005) 353(21):2215-7. doi: 10.1056/ NEJMp058251

3. Heck JE, Ritz B, Hung RJ, Hashibe M, Boffetta P. The epidemiology of neuroblastoma: a review. Paediatr Perinat Epidemiol (2009) 23(2):125-43. doi: 10.1111/j.1365-3016.2008.00983.x

4. Forouzani-Moghaddam MJ, Nabian P, Gholami A, Dehghanbaghi N, Azizipanah M, Jokar K, et al. A review of neuroblastoma: prevalence, diagnosis, related genetic factors, and treatment. Iran J Pediatr Hematol Oncol (2018) 8(4):237-46 doi: 10.1038/nature11247

5. Brodeur GM. Spontaneous regression of neuroblastoma. Cell Tissue Res (2018) 372(2):277-86. doi: 10.1007/s00441-017-2761-2

6. Brinkschmidt C, Christiansen H, Terpe HJ, Simon R, Lampert F, Boecker W, et al. Distal chromosome 17 gains in neuroblastomas detected by comparative genomic hybridization (CGH) are associated with a poor clinical outcome. Med Pediatr Oncol (2001) 36(1):11-3. doi: 10.1002/ 1096-911X(20010101)36:1<11::AID-MPO1004>3.0.CO;2-M

7. Vandesompele J, Baudis M, De Preter K, Van Roy N, Ambros P, Bown N, et al. Unequivocal delineation of clinicogenetic subgroups and development of a new model for improved outcome prediction in neuroblastoma. J Clin Oncol Off J Am Soc Clin Oncol (2005) 23(10):2280-99. doi: 10.1200/ JCO.2005.06.104

8. Plantaz D, Vandesompele J, Van Roy N, Lastowska M, Bown N, Combaret V, et al. Comparative genomic hybridization (CGH) analysis of stage 4 neuroblastoma reveals high frequency of $11 \mathrm{q}$ deletion in tumors lacking MYCN amplification. Int J Cancer (2001) 91(5):680-6. doi: 10.1002/1097-0215(200002)9999:9999<::AIDIJC1114>3.0.CO;2-R

9. Breen CJ, O'Meara A, McDermott M, Mullarkey M, Stallings RL. Coordinate deletion of chromosome $3 p$ and $11 \mathrm{q}$ in neuroblastoma detected by comparative genomic hybridization. Cancer Genet Cytogenet (2000) 120(1):44-9. doi: 10.1016/S0165-4608(99)00252-6

10. Stallings RL. MicroRNA involvement in the pathogenesis of neuroblastoma: potential for microRNA mediated therapeutics. Curr Pharm Des (2009) 15 (4):456-62. doi: 10.2174/138161209787315837

11. Palazzo AF, Lee ES. Non-coding RNA: what is functional and what is junk? Front Genet (2015) 6:2. doi: 10.3389/fgene.2015.00002

12. Dunham I, Birney E, Lajoie BR, Sanyal A, Dong X, Greven M, et al. An integrated encyclopedia of DNA elements in the human genome2012. Nature (2012) 498(7414):57-74. doi: 10.1038/nature11247

13. Chen Y, Stallings RL. Differential patterns of microRNA expression in neuroblastoma are correlated with prognosis, differentiation, and apoptosis. Cancer Res (2007) 67(3):976-83. doi: 10.1158/0008-5472.CAN06-3667

14. Welch C, Chen Y, Stallings RL. MicroRNA-34a functions as a potential tumor suppressor by inducing apoptosis in neuroblastoma cells. Oncogene (2007) 26(34):5017-22. doi: 10.1038/sj.onc.1210293

15. Cole KA, Attiyeh EF, Mosse YP, Laquaglia MJ, Diskin SJ, Brodeur GM, et al. A functional screen identifies miR-34a as a candidate neuroblastoma tumor suppressor gene. Mol Cancer Res (2008) 6(5):735-42. doi: 10.1158/15417786.MCR-07-2102

16. Wei JS, Song YK, Durinck S, Chen QR, Cheuk AT, Tsang P, et al. The MYCN oncogene is a direct target of miR-34a. Oncogene (2008) 27 (39):5204-13. doi: 10.1038/onc.2008.154

\section{AUTHOR CONTRIBUTIONS}

MT and SG-F wrote the draft and revised it. OR, KHT, and MH performed the data collection, designed the tables and figures. All authors contributed to the article and approved the submitted version.

17. Chen J, Hongting L, Shaoping L, Xin C, Qian D. MiR-34-a acts as a suppressor in neuroblastoma progression by targeting CD44. J Pak Med Assoc (2017) 67(10):1524-31.

18. Cheng X, Xu Q, Zhang Y, Shen M, Zhang S, Mao F, et al. miR-34a inhibits progression of neuroblastoma by targeting autophagy-related gene 5. Eur J Pharmacol (2019) 850:53-63. doi: 10.1016/j.ejphar.2019.01.071

19. Misra S, Hascall VC, Markwald RR, Ghatak S. Interactions between Hyaluronan and Its Receptors (CD44, RHAMM) Regulate the Activities of Inflammation and Cancer. Front Immunol (2015) 6:201-1. doi: 10.3389/ fimmu.2015.00201

20. Guo H, Chitiprolu M, Roncevic L, Javalet C, Hemming FJ, Trung MT, et al. Atg5 disassociates the V1V0-ATPase to promote exosome production and tumor metastasis independent of canonical macroautophagy. Dev Cell (2017) 43(6):716-730. e7. doi: 10.1016/j.devcel.2017.11.018

21. Bray I, Tivnan A, Bryan K, Foley NH, Watters KM, Tracey L, et al. MicroRNA-542-5p as a novel tumor suppressor in neuroblastoma. Cancer Lett (2011) 303(1):56-64. doi: 10.1016/j.canlet.2011.01.016

22. Wang J, Zhang X, Yao H, Le Y, Zhou W, Li J, et al. MiR-490-5p functions as tumor suppressor in childhood neuroblastoma by targeting MYEOV. Hum Cell (2020) 33(1):261-71. doi: 10.1007/s13577-019-00302-Z

23. Cao X, Sun Z, Zhang L, Chen M, Yuan B. microRNA-144-3p suppresses human neuroblastoma cell proliferation by targeting HOXA7. Eur Rev Med Pharmacol Sci (2019) 23(2):716-23. doi: 10.26355/eurrev_201901_16885

24. Li Z, Chen H. miR-34a inhibits proliferation, migration and invasion of paediatric neuroblastoma cells via targeting HNF4 $\alpha$. Artif Cells Nanomed Biotechnol (2019) 47(1):3072-8. doi: 10.1080/21691401.2019.1637886

25. Sadra K.B.K.H.A., Huh S-O. Targeting the Difficult-to-Drug CD71 and MYCN with Gambogic Acid and Vorinostat in a Class of Neuroblastomas. Cell Physiol Biochem (2019) 53:258-80. doi: 10.33594/000000134

26. Lodrini M, Poschmann G, Schmidt V, Ẅnschel J, Dreidax D, Witt O, et al. Minichromosome maintenance complex is a critical node in the miR-183 signaling network of MYCN-amplified neuroblastoma cells. J Proteome Res (2016) 15(7):2178-86. doi: 10.1021/acs.jproteome.6b00134

27. Soriano A, Masanas M, Boloix A, Masiá N, París-Coderch L, Piskareva O, et al. Functional high-throughput screening reveals miR-323a-5p and miR$342-5 \mathrm{p}$ as new tumor-suppressive microRNA for neuroblastoma. Cell Mol Life Sci (2019) 76(11):2231-43. doi: 10.1007/s00018-019-03041-4

28. Bettinsoli P, Ferrari-Toninelli G, Bonini S, Prandelli C, Memo M. Notch ligand Delta-like 1 as a novel molecular target in childhood neuroblastoma. BMC Cancer (2017) 17(1):1-12. doi: 10.1186/s12885-017-3340-3

29. Liu H, Huang H, Li R, Bi W, Feng L, Lingling E, et al. Mitophagy protects SH-SY5Y neuroblastoma cells against the TNF $\alpha$-induced inflammatory injury: involvement of microRNA-145 and Bnip3. Biomed Pharmacother (2019) 109:957-68. doi: 10.1016/j.biopha.2018.10.123

30. Zhao Z, Partridge V, Sousares M, Shelton SD, Holland CL, Pertsemlidis A, et al. microRNA-2110 functions as an onco-suppressor in neuroblastoma by directly targeting Tsukushi. PloS One (2018) 13(12):e0208777. doi: 10.1371/ journal.pone.0208777

31. Neviani P, Wise PM, Murtadha M, Liu CW, Wu C-H, Jong AY, et al. Natural killer-derived exosomal miR-186 inhibits neuroblastoma growth and immune escape mechanisms. Cancer Res (2019) 79(6):1151-64. doi: 10.1158/0008-5472.CAN-18-0779

32. Wang $\mathrm{X}-\mathrm{H}, \mathrm{Wu} \mathrm{H}-\mathrm{Y}$, Gao J, Wang X-H, Gao T-H, Zhang S-F. FGF represses metastasis of neuroblastoma regulated by MYCN and TGF- $\beta 1$ induced LMO1 via control of let-7 expression. Brain Res (2019) 1704:219-28. doi: 10.1016/j.brainres.2018.10.015

33. Lozier AM, Rich ME, Grawe AP, Peck AS, Zhao P, Chang AT-T, et al. Targeting ornithine decarboxylase reverses the LIN28/Let-7 axis and inhibits glycolytic metabolism in neuroblastoma. Oncotarget (2015) 6(1):196. doi: 10.18632 /oncotarget.2768 
34. Powers JT, Tsanov KM, Pearson DS, Roels F, Spina CS, Ebright R, et al. Multiple mechanisms disrupt the let-7 microRNA family in neuroblastoma. Nature (2016) 535(7611):246-51. doi: 10.1038/nature18632

35. Marengo B, Monti P, Miele M, Menichini P, Ottaggio L, Foggetti G, et al. Etoposide-resistance in a neuroblastoma model cell line is associated with 13q14. 3 mono-allelic deletion and miRNA-15a/16-1 down-regulation. Sci Rep (2018) 8(1):1-15. doi: 10.1038/s41598-018-32195-7

36. Klein S, Abraham M, Bulvik B, Dery E, Weiss ID, Barashi N, et al. CXCR4 Promotes Neuroblastoma Growth and Therapeutic Resistance through miR15a/16-1-Mediated ERK and BCL2/Cyclin D1 Pathways. Cancer Res (2018) 78(6):1471-83. doi: 10.1158/0008-5472.CAN-17-0454

37. Saeki N, Saito A, Sugaya Y, Amemiya M, Sasaki H. Indirect Down-regulation of Tumor-suppressive let-7 Family MicroRNAs by LMO1 in Neuroblastoma. Cancer Genomics-Proteomics (2018) 15(5):413-20. doi: $10.21873 /$ cgp. 20100

38. Li S-H, Li J-P, Chen L, Liu J-L. miR-146a induces apoptosis in neuroblastoma cells by targeting BCL11A. Med Hypotheses (2018) 117:217. doi: $10.1016 /$ j.mehy.2018.05.019

39. Wang X, Li J, Xu X, Zheng J, Li Q. miR-129 inhibits tumor growth and potentiates chemosensitivity of neuroblastoma by targeting MYO10. Biomed Pharmacother (2018) 103:1312-8. doi: 10.1016/j.biopha.2018.04.153

40. Wu T, Lin Y, Xie Z. MicroRNA-1247 inhibits cell proliferation by directly targeting ZNF346 in childhood neuroblastoma. Biol Res (2018) 51(1):1-10. doi: 10.1186/s40659-018-0162-y

41. Ooi CY, Carter DR, Liu B, Mayoh C, Beckers A, Lalwani A, et al. Network modeling of microRNA-mRNA interactions in neuroblastoma tumorigenesis identifies miR-204 as a direct inhibitor of MYCN. Cancer Res (2018) 78(12):3122-34. doi: 10.1158/0008-5472.CAN-17-3034

42. Watanabe K, Yamaji R, Ohtsuki T. Micro RNA-664a-5p promotes neuronal differentiation of SH-SY 5Y cells. Genes Cells (2018) 23(3):225-33. doi: $10.1111 /$ gtc. 12559

43. Sharif S, Ghahremani MH, Soleimani M. Induction of morphological and functional differentiation of human neuroblastoma cells by miR-124. J Biosci (2017) 42(4):555-63. doi: 10.1007/s12038-017-9714-5

44. Yang K, Tong L, Li K, Zhou Y, Xiao J. A SRSF1 self-binding mechanism restrains Mir505-3p from inhibiting proliferation of neural tumor cell lines. Anti-cancer Drugs (2018) 29(1):40-9. doi: 10.1097/CAD.0000000000000564

45. Xia H-L, Lv Y, Xu C-W, Fu M-C, Zhang T, Yan X-M, et al. MiR-513c suppresses neuroblastoma cell migration, invasion, and proliferation through direct targeting glutaminase (GLS). Cancer Biomarkers (2017) 20 (4):589-96. doi: 10.3233/CBM-170577

46. Chen S, Jin L, Nie S, Han L, Lu N, Zhou Y. miR-205 inhibits neuroblastoma growth by targeting cAMP-responsive element-binding protein 1. Oncol Res Featuring Preclinical Clin Cancer Ther (2018) 26(3):445-55. doi: 10.3727/ 096504017X14974834436195

47. Megiorni F, Colaiacovo M, Cialfi S, McDowell HP, Guffanti A, Camero S, et al. A sketch of known and novel MYCN-associated miRNA networks in neuroblastoma. Oncol Rep (2017) 38(1):3-20. doi: 10.3892/or.2017.5701

48. Samaraweera L, Spengler BA, Ross RA. Reciprocal antagonistic regulation of $\mathrm{N}$-myc mRNA by miR-17 and the neuronal-specific RNA-binding protein HuD. Oncol Rep (2017) 38(1):545-50. doi: 10.3892/or.2017.5664

49. Xu Y, Chen X, Lin L, Chen H, Yu S, Li D. MicroRNA-149 is associated with clinical outcome in human neuroblastoma and modulates cancer cell proliferation through Rap1 independent of MYCN amplification. Biochimie (2017) 139:1-8. doi: 10.1016/j.biochi.2017.04.011

50. Zhao G, Wang G, Bai H, Li T, Gong F, Yang H, et al. Targeted inhibition of HDAC8 increases the doxorubicin sensitivity of neuroblastoma cells via up regulation of miR-137. Eur J Pharmacol (2017) 802:20-6. doi: 10.1016/ j.ejphar.2017.02.035

51. Ren X, Bai X, Zhang X, Li Z, Tang L, Zhao X, et al. Quantitative nuclear proteomics identifies that miR-137-mediated EZH2 reduction regulates resveratrol-induced apoptosis of neuroblastoma cells. Mol Cell Proteomics (2015) 14(2):316-28. doi: 10.1074/mcp.M114.041905

52. Yang H-J, Ju F, Guo X-X, Ma S-P, Wang L, Cheng B-F, et al. RNA-binding protein RBM3 prevents NO-induced apoptosis in human neuroblastoma cells by modulating p38 signaling and miR-143. Sci Rep (2017) 7(1):1-11. doi: $10.1038 /$ srep 41738
53. Boyineni J, Tanpure S, Gnanamony M, Antony R, Fernández KS, Lin J, et al. SPARC overexpression combined with radiation retards angiogenesis by suppressing VEGF-A via miR-410 in human neuroblastoma cells. Int $J$ Oncol (2016) 49(4):1394-406. doi: 10.3892/ijo.2016.3646

54. Fabbri E, Montagner G, Bianchi N, Finotti A, Borgatti M, Lampronti I, et al. MicroRNA miR-93-5p regulates expression of IL-8 and VEGF in neuroblastoma SK-N-AS cells. Oncol Rep (2016) 35(5):2866-72. doi: 10.3892/or.2016.4676

55. Wang Z, Lei H, Sun Q. MicroRNA-141 and its associated gene FUS modulate proliferation, migration and cisplatin chemosensitivity in neuroblastoma cell lines. Oncol Rep (2016) 35(5):2943-51. doi: 10.3892/ or.2016.4640

56. Soriano A, París-Coderch L, Jubierre L, Martínez A, Zhou X, Piskareva O, et al. MicroRNA-497 impairs the growth of chemoresistant neuroblastoma cells by targeting cell cycle, survival and vascular permeability genes. Oncotarget (2016) 7(8):9271. doi: 10.18632/oncotarget.7005

57. Liu G, Xu Z, Hao D. MicroRNA-451 inhibits neuroblastoma proliferation, invasion and migration by targeting macrophage migration inhibitory factor. Mol Med Rep (2016) 13(3):2253-60. doi: 10.3892/mmr.2016.4770

58. Zhao D, Tian Y, Li P, Wang L, Xiao A, Zhang M, et al. MicroRNA-203 inhibits the malignant progression of neuroblastoma by targeting Sam68. Mol Med Rep (2015) 12(4):5554-60. doi: 10.3892/mmr.2015.4013

59. Beckers A, Van Peer G, Carter DR, Gartlgruber M, Herrmann C, Agarwal S, et al. MYCN-driven regulatory mechanisms controlling LIN28B in neuroblastoma. Cancer Lett (2015) 366(1):123-32. doi: 10.1016/ j.canlet.2015.06.015

60. Xiang X, Mei H, Zhao X, Pu J, Li D, Qu H, et al. miRNA-337-3p suppresses neuroblastoma progression by repressing the transcription of matrix metalloproteinase 14. Oncotarget (2015) 6(26):22452. doi: 10.18632/ oncotarget.4311

61. Wu K, Yang L, Chen J, Zhao H, Wang J, Xu S, et al. miR-362-5p inhibits proliferation and migration of neuroblastoma cells by targeting phosphatidylinositol 3-kinase-C2ß. FEBS Lett (2015) 589(15):1911-9. doi: 10.1016/j.febslet.2015.05.056

62. Stigliani S, Scaruffi P, Lagazio C, Persico L, Carlini B, Varesio L, et al. Deregulation of focal adhesion pathway mediated by miR-659-3p is implicated in bone marrow infiltration of stage $\mathrm{M}$ neuroblastoma patients. Oncotarget (2015) 6(15):13295. doi: 10.18632/oncotarget.3745

63. Rihani A, Van Goethem A, Ongenaert M, De Brouwer S, Volders P-J, Agarwal S, et al. Genome wide expression profiling of p53 regulated miRNAs in neuroblastoma. Sci Rep (2015) 5:9027. doi: 10.1038/srep09027

64. Zhao Z, Ma X, Sung D, Li M, Kosti A, Lin G, et al. microRNA-449a functions as a tumor suppressor in neuroblastoma through inducing cell differentiation and cell cycle arrest. RNA Biol (2015) 12(5):538-54. doi: $10.1080 / 15476286.2015 .1023495$

65. Harvey H, Piskareva O, Creevey L, Alcock LC, Buckley PG, O’Sullivan MJ, et al. Modulation of chemotherapeutic drug resistance in neuroblastoma SK$\mathrm{N}-\mathrm{AS}$ cells by the neural apoptosis inhibitory protein and mi R-520f. Int $J$ Cancer (2015) 136(7):1579-88. doi: 10.1002/ijc.29144

66. Althoff K, Lindner S, Odersky A, Mestdagh P, Beckers A, Karczewski S, et al. miR-542-3p exerts tumor suppressive functions in neuroblastoma by downregulating S urvivin. Int J Cancer (2015) 136(6):1308-20. doi: $10.1002 / \mathrm{ijc} .29091$

67. Schulte JH, Horn S, Otto T, Samans B, Heukamp LC, Eilers UC, et al. MYCN regulates oncogenic MicroRNAs in neuroblastoma. Int J Cancer (2008) 122 (3):699-704. doi: 10.1002/ijc.23153

68. Fontana L, Fiori ME, Albini S, Cifaldi L, Giovinazzi S, Forloni M, et al. Antagomir-17-5p abolishes the growth of therapy-resistant neuroblastoma through p21 and BIM. PloS One (2008) 3(5):e2236. doi: 10.1371/ journal.pone.0002236

69. Wu JC, Jiang HM, Yang XH, Zheng HC. ING5-mediated antineuroblastoma effects of suberoylanilide hydroxamic acid. Cancer Med (2018) 7(9):4554-69. doi: $10.1002 /$ cam 4.1634

70. Li Z, Xu Z, Xie Q, Gao W, Xie J, Zhou L. miR-1303 promotes the proliferation of neuroblastoma cell SH-SY5Y by targeting GSK3 $\beta$ and SFRP1. Biomed Pharmacother (2016) 83:508-13. doi: 10.1016/ j.biopha.2016.07.010 
71. Chen J, Wang P, Cai R, Peng H, Zhang C, Zhang M. SLC 34A2 promotes neuroblastoma cell stemness via enhancement of miR-25/Gsk3 $\beta$-mediated activation of Wnt/ß-catenin signaling. FEBS Open Bio (2019) 9(3):527-37. doi: 10.1002/2211-5463.12594

72. Nowak I, Boratyn E, Durbas M, Horwacik I, Rokita H. Exogenous expression of miRNA-3613-3p causes APAF1 downregulation and affects several proteins involved in apoptosis in BE (2)-C human neuroblastoma cells. Int J Oncol (2018) 53(4):1787-99. doi: 10.3892/ijo.2018.4509

73. Liu X, Peng H, Liao W, Luo A, Cai M, He J, et al. MiR-181a/b induce the growth, invasion, and metastasis of neuroblastoma cells through targeting ABI1. Mol Carcinogenesis (2018) 57(9):1237-50. doi: 10.1002/mc.22839

74. Jiang J, Song X, Yang J, Lei K, Ni Y, Zhou F, et al. Triptolide inhibits proliferation and migration of human neuroblastoma SH-SY5Y cells by upregulating microRNA-181a. Oncol Res Featuring Preclinical Clin Cancer Ther (2018) 26(8):1235-43. doi: 10.3727/096504018X15179661552702

75. Cheng M, Liu L, Lao Y, Liao W, Liao M, Luo X, et al. MicroRNA-181a suppresses parkin-mediated mitophagy and sensitizes neuroblastoma cells to mitochondrial uncoupler-induced apoptosis. Oncotarget (2016) 7(27):42274. doi: 10.18632 /oncotarget.9786

76. He X-y, Tan Z-1, Mou Q, Liu F-j, Liu S, Yu C-w, et al. MicroRNA-221 enhances MYCN via targeting nemo-like kinase and functions as an oncogene related to poor prognosis in neuroblastoma. Clin Cancer Res (2017) 23(11):2905-18. doi: 10.1158/1078-0432.CCR-16-1591

77. Qu H, Zheng L, Song H, Jiao W, Li D, Fang E, et al. microRNA-558 facilitates the expression of hypoxia-inducible factor 2 alpha through binding to $5^{\prime}$ untranslated region in neuroblastoma. Oncotarget (2016) 7(26):40657. doi: 10.18632/oncotarget.9813

78. Qu H, Zheng L, Pu J, Mei H, Xiang X, Zhao X, et al. miRNA-558 promotes tumorigenesis and aggressiveness of neuroblastoma cells through activating the transcription of heparanase. Hum Mol Genet (2015) 24(9):2539-51. doi: $10.1093 / \mathrm{hmg} / \mathrm{ddv} 018$

79. Chen Y, Tsai Y-H, Tseng B-J, Pan H-Y, Tseng S-H. Suppression of miR-19b enhanced the cytotoxic effects of mTOR inhibitors in human neuroblastoma cells. J Pediatr Surg (2016) 51(11):1818-25. doi: 10.1016/ j.jpedsurg.2016.07.003

80. Li Y, Shang YM, Wang QW. MicroRNA-21 promotes the proliferation and invasion of neuroblastoma cells through targeting CHL1. Minerva Med (2016) 107(5):287-93.

81. Maugeri M, Barbagallo D, Barbagallo C, Banelli B, Di Mauro S, Purrello F, et al. Altered expression of miRNAs and methylation of their promoters are correlated in neuroblastoma. Oncotarget (2016) 7(50):83330. doi: 10.18632/ oncotarget. 13090

82. Zhou Y, Sheng B. Association of microRNA 21 with biological features and prognosis of neuroblastoma. Cancer Control (2016) 23(1):78-84. doi: $10.1177 / 107327481602300113$

83. Fernandes JCR, Acuña SM, Aoki JI, Floeter-Winter LM, Muxel SM. Long Non-Coding RNAs in the Regulation of Gene Expression: Physiology and Disease. Noncoding RNA (2019) 5(1):17. doi: 10.3390/ncrna5010017

84. Prajapati B, Fatma M, Fatima M, Khan MT, Sinha S, Seth PK. Identification of IncRNAs Associated With Neuroblastoma in Cross-Sectional Databases: Potential Biomarkers. Front Mol Neurosci (2019) 12:293-3. doi: 10.3389/ fnmol.2019.00293

85. Pandey GK, Mitra S, Subhash S, Hertwig F, Kanduri M, Mishra K, et al. The risk-associated long noncoding RNA NBAT-1 controls neuroblastoma progression by regulating cell proliferation and neuronal differentiation. Cancer Cell (2014) 26(5):722-37. doi: 10.1016/j.ccell.2014.09.014

86. Liu PY, Erriquez D, Marshall GM, Tee AE, Polly P, Wong M, et al. Effects of a novel long noncoding RNA, lncUSMycN, on N-Myc expression and neuroblastoma progression. JNCI: J Natl Cancer Inst (2014) 106(7):dju113. doi: $10.1093 /$ jnci/dju113

87. Barnhill LM, Williams RT, Cohen O, Kim Y, Batova A, Mielke JA, et al. High expression of CAI2, a 9p21-embedded long noncoding RNA, contributes to advanced-stage neuroblastoma. Cancer Res (2014) 74(14):3753-63. doi: 10.1158/0008-5472.CAN-13-3447

88. Watters KM, Bryan K, Foley NH, Meehan M, Stallings RL. Expressional alterations in functional ultra-conserved non-coding RNAs in response to all-trans retinoic acid-induced differentiation in neuroblastoma cells. BMC Cancer (2013) 13:184. doi: 10.1186/1471-2407-13-184
89. Yu M, Ohira M, Li Y, Niizuma H, Oo ML, Zhu Y, et al. High expression of ncRAN, a novel non-coding RNA mapped to chromosome 17q25.1, is associated with poor prognosis in neuroblastoma. Int J Oncol (2009) 34 (4):931-8. doi: 10.3892/ijo_00000219

90. Li C, Wang S, Yang C. Long non-coding RNA DLX6-AS1 regulates neuroblastoma progression by targeting YAP1 via miR-497-5p. Life Sci (2020), 252:117657. doi: 10.1016/j.lfs.2020.117657

91. Hu Y, Sun H, Hu J, Zhang X. LncRNA DLX6-AS1 Promotes the Progression of Neuroblastoma by Activating STAT2 via Targeting miR-506-3p. Cancer Manage Res (2020) 12:7451-63. doi: 10.2147/CMAR.S252521

92. Liu PY, Tee AE, Milazzo G, Hannan KM, Maag J, Mondal S, et al. The long noncoding RNA lncNB1 promotes tumorigenesis by interacting with ribosomal protein RPL35. Nat Commun (2019) 10(1):1-17. doi: 10.1038/ s41467-019-12971-3

93. Shatara M, Xavier AC, Dombkowski A, Cukovic D, Poulik JM, Altinok D, et al. Monozygotic twins with neuroblastoma MS have a similar molecular profile: a case of twin-to-twin metastasis. Br J Cancer (2019) 121(10):890-3. doi: 10.1038/s41416-019-0594-3

94. Wang J, Wang Z, Yao W, Dong K, Zheng S, Li K. The association between IncRNA LINC01296 and the clinical characteristics in neuroblastoma. J Pediatr Surg (2019) 54(12):2589-94. doi: 10.1016/ j.jpedsurg.2019.08.032

95. Yu Y, Chen F, Yang Y, Jin Y, Shi J, Han S, et al. lncRNA SNHG16 is associated with proliferation and poor prognosis of pediatric neuroblastoma. Int J Oncol (2019) 55(1):93-102. doi: 10.3892/ijo.2019.4813

96. Xu Z, Sun Y, Wang D, Sun H, Liu X. SNHG16 promotes tumorigenesis and cisplatin resistance by regulating miR-338-3p/PLK4 pathway in neuroblastoma cells. Cancer Cell Int (2020) 20(1):1-13. doi: 10.1186/ s12935-020-01291-y

97. Bao J, Zhang S, Meng Q, Qin T. SNHG16 Silencing Inhibits Neuroblastoma Progression by Downregulating HOXA7 via Sponging miR-128-3p. Neurochem Res (2020), 1-12. doi: 10.1007/s11064-020-02955-x

98. Deng D, Yang S, Wang X. Long non-coding RNA SNHG16 regulates cell behaviors through miR-542-3p/HNF4 $\alpha$ axis via RAS/RAF/MEK/ERK signaling pathway in pediatric neuroblastoma cells. Biosci Rep (2020) 40 (5). doi: 10.1042/BSR20200723

99. Wen Y, Gong X, Dong Y, Tang C. Long Non Coding RNA SNHG16 Facilitates Proliferation, Migration, Invasion and Autophagy of Neuroblastoma Cells via Sponging miR-542-3p and Upregulating ATG5 Expression. OncoTargets Ther (2020) 13:263. doi: 10.2147/OTT.S226915

100. Li E-y, Zhao P-j, Jian J, Yin B-q, Sun Z-y, Xu C-x, et al. LncRNA MIAT overexpression reduced neuron apoptosis in a neonatal rat model of hypoxic-ischemic injury through miR-211/GDNF. Cell Cycle (2019) 18 (2):156-66. doi: 10.1080/15384101.2018.1560202

101. Chi R, Chen X, Liu M, Zhang H, Li F, Fan X, et al. Role of SNHG7-miR-6535p-STAT2 feedback loop in regulating neuroblastoma progression. J Cell Physiol (2019) 234(8):13403-12. doi: 10.1002/jcp.28017

102. Wang S, Wang X, Zhang C. LncRNA SNHG7 enhances chemoresistance in neuroblastoma through cisplatin-induced autophagy by regulating miR-3293p/MYO10 axis. Eur Rev Med Pharmacol Sci (2020) 24(7):3805-17. doi: 10.26355/eurrev_202004_20847

103. Jia J, Zhang D, Zhang J, Yang L, Zhao G, Yang H, et al. Long non-coding RNA SNHG7 promotes neuroblastoma progression through sponging miR323a-5p and miR-342-5p. Biomed Pharmacother (2020) 128:110293. doi: 10.1016/j.biopha.2020.110293

104. Pan J, Zhang D, Zhang J, Qin P, Wang J. LncRNA RMRP silence curbs neonatal neuroblastoma progression by regulating microRNA-206/ tachykinin-1 receptor axis via inactivating extracellular signal-regulated kinases. Cancer Biol Ther (2019) 20(5):653-65. doi: 10.1080/ 15384047.2018.1550568

105. Yang T-W, Sahu D, Chang Y-W, Hsu C-L, Hsieh C-H, Huang H-C, et al. RNA-binding proteomics reveals MATR3 interacting with lncRNA SNHG1 to enhance neuroblastoma progression. J Proteome Res (2018) 18(1):406-16. doi: 10.1021/acs.jproteome.8b00693

106. Sahu D, Hsu C-L, Lin C-C, Yang T-W, Hsu W-M, Ho S-Y, et al. Coexpression analysis identifies long noncoding RNA SNHG1 as a novel predictor for event-free survival in neuroblastoma. Oncotarget (2016) 7 (36):58022. doi: 10.18632/oncotarget.11158 
107. Chai P, Jia R, Jia R, Pan H, Wang S, Ni H, et al. Dynamic chromosomal tuning of a novel GAU1 lncing driver at chr12p13. 32 accelerates tumorigenesis. Nucleic Acids Res (2018) 46(12):6041-56. doi: 10.1093/nar/ gky366

108. O'Brien EM, Selfe JL, Martins AS, Walters ZS, Shipley JM. The long noncoding RNA MYCNOS-01 regulates MYCN protein levels and affects growth of MYCN-amplified rhabdomyosarcoma and neuroblastoma cells. BMC Cancer (2018) 18(1):1-13. doi: 10.1186/s12885-018-4129-8

109. Li D, Wang X, Mei H, Fang E, Ye L, Song H, et al. Long noncoding RNA pancEts-1 promotes neuroblastoma progression through hnRNPK-mediated $\beta$-catenin stabilization. Cancer Res (2018) 78(5):1169-83. doi: 10.1158/00085472.CAN-17-2295

110. Bi S, Wang C, Li Y, Zhang W, Zhang J, Lv Z, et al. LncRNA-MALAT1mediated Axl promotes cell invasion and migration in human neuroblastoma. Tumor Biol (2017) 39(5). 1010428317699796. doi: 10.1177/ 1010428317699796

111. Tee AE, Liu B, Song R, Li J, Pasquier E, Cheung BB, et al. The long noncoding RNA MALAT1 promotes tumor-driven angiogenesis by up-regulating proangiogenic gene expression. Oncotarget (2016) 7(8):8663. doi: 10.18632/ oncotarget. 6675

112. Tee AE, Ling D, Nelson C, Atmadibrata B, Dinger ME, Xu N, et al. The histone demethylase JMJD1A induces cell migration and invasion by upregulating the expression of the long noncoding RNA MALAT1. Oncotarget (2014) 5(7):1793. doi: 10.18632/oncotarget.1785

113. Mazar J, Rosado A, Shelley J, Marchica J, Westmoreland TJ. The long noncoding RNA GAS5 differentially regulates cell cycle arrest and apoptosis through activation of BRCA1 and p53 in human neuroblastoma. Oncotarget (2017) 8(4):6589. doi: 10.18632/oncotarget.14244

114. Tang W, Dong K, Li K, Dong R, Zheng S. MEG3, HCN3 and linc01105 influence the proliferation and apoptosis of neuroblastoma cells via the HIF- $1 \alpha$ and p53 pathways. Sci Rep (2016) 6(1):1-9. doi: 10.1038/ srep36268

115. Liu PY, Atmadibrata B, Mondal S, Tee AE, Liu T. NCYM is upregulated by IncUSMycN and modulates N-Myc expression. Int J Oncol (2016) 49 (6):2464-70. doi: 10.3892/ijo.2016.3730

116. Yarmishyn AA, Batagov AO, Tan JZ, Sundaram GM, Sampath P, Kuznetsov VA, et al. HOXD-AS1 is a novel lncRNA encoded in HOXD cluster and a marker of neuroblastoma progression revealed via integrative analysis of noncoding transcriptome. BMC Genomics (2014) 15(S9):S7. doi: 10.1186/ 1471-2164-15-S9-S7

117. Pavlaki I, Alammari F, Sun B, Clark N, Sirey T, Lee S, et al. The long noncoding RNA Paupar promotes KAP 1-dependent chromatin changes and regulates olfactory bulb neurogenesis. EMBO J (2018) 37(10):e98219. doi: 10.15252/embj.201798219

118. Vance KW, Sansom SN, Lee S, Chalei V, Kong L, Cooper SE, et al. The long non-coding RNA P aupar regulates the expression of both local and distal genes. EMBO J (2014) 33(4):296-311. doi: 10.1002/embj.201386225

119. Wang B, Xu L, Zhang J, Cheng X, Xu Q, Wang J, et al. LncRNA NORAD accelerates the progression and doxorubicin resistance of neuroblastoma through up-regulating HDAC8 via sponging miR-144-3p. Biomed Pharmacother (2020) 129:110268. doi: 10.1016/j.biopha.2020.110268

120. Yu Z, Zhang J, Han J. Silencing CASC11 curbs neonatal neuroblastoma progression through modulating microRNA-676-3p/nucleolar protein 4 like (NOL4L) axis. Pediatr Res (2020) 87(4):662-8. doi: 10.1038/s41390-0190625-Z

121. Nie L, Li C, Zhao T, Wang Y, Liu J. LncRNA double homeobox A pseudogene 8 (DUXAP8) facilitates the progression of neuroblastoma and activates Wnt/ $\beta$-catenin pathway via microRNA-29/nucleolar protein 4 like (NOL4L) axis. Brain Res (2020) 1746:146947. doi: 10.1016/ j.brainres.2020.146947

122. Yang H, Guo J, Zhang M, Li A. LncRNA SNHG4 promotes neuroblastoma proliferation, migration, and invasion by sponging miR-377-3p. Neoplasma (2020) 67:1054-62. doi: 10.4149/neo_2020_191023N1081

123. Zhao X, Li D, Yang F, Lian H, Wang J, Wang X, et al. Long Noncoding RNA NHEG1 Drives $\beta$-Catenin Transactivation and Neuroblastoma Progression through Interacting with DDX5. Mol Ther (2020) 28(3):946-62. doi: 10.1016/j.ymthe.2019.12.013
124. Mu L, Wang L, Zhang S, Wang Q. Long noncoding RNA XIST suppresses tumorigenesis and enhances radiosensitivity in neuroblastoma cells through regulating miR-653-5p/HK2 axis. (2020). doi: 10.2147/OTT.S170439

125. Tian C, Li Z, Zhang L, Dai D, Huang Q, Liu J, et al. lncRNA NR_120420 promotes SH-SY5Y cells apoptosis by regulating NF- $\mathrm{KB}$ after oxygen and glucose deprivation. Gene (2020) 728:144285. doi: 10.1016/ j.gene.2019.144285

126. Russell MR, Penikis A, Oldridge DA, Alvarez-Dominguez JR, McDaniel L, Diamond M, et al. CASC15-S is a tumor suppressor IncRNA at the 6p22 neuroblastoma susceptibility locus. Cancer Res (2015) 75(15):3155-66. doi: 10.1158/0008-5472.CAN-14-3613

127. Mondal T, Juvvuna PK, Kirkeby A, Mitra S, Kosalai ST, Traxler L, et al. Sense-antisense lncRNA pair encoded by locus 6 p22. 3 determines neuroblastoma susceptibility via the USP36-CHD7-SOX9 regulatory axis. Cancer Cell (2018) 33(3):417-434. e7. doi: 10.1016/j.ccell.2018.01.020

128. Zhao X, Li D, Huang D, Song H, Mei H, Fang E, et al. Risk-associated long noncoding RNA FOXD3-AS1 inhibits neuroblastoma progression by repressing PARP1-mediated activation of CTCF. Mol Ther (2018) 26 (3):755-73. doi: 10.1016/j.ymthe.2017.12.017

129. Bevilacqua V, Gioia U, Di Carlo V, Tortorelli AF, Colombo T, Bozzoni I, et al. Identification of linc-NeD125, a novel long non coding RNA that hosts miR-125b-1 and negatively controls proliferation of human neuroblastoma cells. RNA Biol (2015) 12(12):1323-37. doi: 10.1080/15476286.2015.1096488

130. Vadie N, Saayman S, Lenox A, Ackley A, Clemson M, Burdach J, et al. MYCNOS functions as an antisense RNA regulating MYCN. RNA Biol (2015) 12(8):893-9. doi: 10.1080/15476286.2015.1063773

131. Zhou X, Lu H, Li F, Han L, Zhang H, Jiang Z, et al. LncRNA cancer susceptibility candidate (CASC7) upregulates phosphatase and tensin homolog by downregulating miR-10a to inhibit neuroblastoma cell proliferation. Neuroreport (2020) 31(5):381-6. doi: 10.1097/ WNR.0000000000001411

132. Li MM, Liu XH, Zhao YC, Ma XY, Zhou YC, Zhao YX, et al. Long noncoding RNA KCNQ1OT1 promotes apoptosis in neuroblastoma cells by regulating miR-296-5p/Bax axis. FEBS J (2020) 287(3):561-77. doi: 10.1111/febs.15047

133. Pan W, Wu A, Yu H, Yu Q, Zheng B, Yang W, et al. NEAT1 Negatively Regulates Cell Proliferation and Migration of Neuroblastoma Cells by miR183-5p/FOXP1 Via the ERK/AKT Pathway. Cell Transplant (2020) 29:0963689720943608. doi: 10.1177/0963689720943608

134. Lu W-Y. Roles of the circular RNA circ-Foxo3 in breast cancer progression. Cell Cycle (2017) 16(7):589. doi: 10.1080/15384101.2017.1278935

135. Yang J, Yu L, Yan J, Xiao Y, Li W, Xiao J, et al. Circular RNA DGKB Promotes the Progression of Neuroblastoma by Targeting miR-873/GLI1 Axis. Front Oncol (2020) 10:1104. doi: 10.3389/fonc.2020.01104

136. Li H, Yang F, Hu A, Wang X, Fang E, Chen Y, et al. Therapeutic targeting of circ-CUX 1/EWSR 1/MAZ axis inhibits glycolysis and neuroblastoma progression. EMBO Mol Med (2019) 11(12):e10835. doi: 10.15252/ emmm.201910835

137. Li Y, Zhuo Z-J, Zhou H, Liu J, Liu Z, Zhang J, et al. Additional data support the role of LINC00673 rs11655237 C> T in the development of neuroblastoma. Aging (Albany NY) (2019) 11(8):2369. doi: 10.18632/ aging. 101920

138. Hu C, Yang T, Pan J, Zhang J, Yang J, He J, et al. Associations between H19 polymorphisms and neuroblastoma risk in Chinese children. Biosci Rep (2019) 39(4). doi: 10.1042/BSR20181582

139. Bayarmaa B, Wu Z, Peng J, Wang Y, Xu S, Yan T, et al. Association of LncRNA MEG3 polymorphisms with efficacy of neoadjuvant chemotherapy in breast cancer. BMC Cancer (2019) 19(1):877. doi: 10.1186/s12885-0196077-3

140. Yang X, He J, Chang Y, Luo A, Luo A, Zhang J, et al. HOTAIR gene polymorphisms contribute to increased neuroblastoma susceptibility in Chinese children. Cancer (2018) 124(12):2599-606. doi: 10.1002/cncr.31353

141. Li Y, Zhuo Z-J, Zhou H, Liu J, Xiao Z, Xiao Y, et al. miR-34b/c rs4938723 T> C Decreases Neuroblastoma Risk: A Replication Study in the Hunan Children. Dis Markers (2019) 2019). doi: 10.1155/2019/6514608

142. Zhuo Z-J, Zhang R, Zhang J, Zhu J, Yang T, Zou Y, et al. Associations between IncRNA MEG3 polymorphisms and neuroblastoma risk in Chinese children. Aging (Albany NY) (2018) 10(3):481. doi: 10.18632/aging.101406 
143. Zhang Z, Chang Y, Jia W, Zhang J, Zhang R, Zhu J, et al. LINC00673 rs11655237 C> T confers neuroblastoma susceptibility in Chinese population. Biosci Rep (2018) 38(1). doi: 10.1042/BSR20171667

144. Pan J, Lin H, Yang T, Yang J, Hu C, Zhu J, et al. IncRNA-uc003opf. 1 rs11752942 A> G polymorphism decreases neuroblastoma risk in Chinese children. Cell Cycle (2020) 19:1-6. doi: 10.1080/15384101.2020.1808382

145. Yang T, Zhang Z, Zhang J, Tan T, Yang J, Pan J, et al. The rs2147578 C> G polymorphism in the Inc-LAMC2-1: 1 gene is associated with increased neuroblastoma risk in the Henan children. BMC Cancer (2018) 18(1):948. doi: 10.1186/s12885-018-4847-y

146. Scaruffi P, Stigliani S, Moretti S, Coco S, De Vecchi C, Valdora F, et al. Transcribed-Ultra Conserved Region expression is associated with outcome in high-risk neuroblastoma. BMC Cancer (2009) 9:441-1. doi: 10.1186/14712407-9-441

147. Thiele CJ, Reynolds CP, Israel MA. Decreased expression of $\mathrm{N}$-myc precedes retinoic acid-induced morphological differentiation of human neuroblastoma. Nature (1985) 313(6001):404-6. doi: 10.1038/313404a0

148. Boloix A, París-Coderch L, Soriano A, Roma J, Gallego S, de Toledo JS, et al. Novel micro RNA-based therapies for the treatment of neuroblastoma.
Anales Pediatr (English Ed) (2016) 85(2):109. e1-109. e6. doi: 10.1016/ j.anpede.2015.07.032

149. Vermeulen J, De Preter K, Naranjo A, Vercruysse L, Van Roy N, Hellemans J, et al. Predicting outcomes for children with neuroblastoma using a multigene-expression signature: a retrospective SIOPEN/COG/GPOH study. Lancet Oncol (2009) 10(7):663-71. doi: 10.1016/S1470-2045(09) 70154-8

Conflict of Interest: The authors declare that the research was conducted in the absence of any commercial or financial relationships that could be construed as a potential conflict of interest.

Copyright (c) 2021 Rezaei, Honarmand Tamizkar, Hajiesmaeili, Taheri and Ghafouri-Fard. This is an open-access article distributed under the terms of the Creative Commons Attribution License (CC BY). The use, distribution or reproduction in other forums is permitted, provided the original author(s) and the copyright owner(s) are credited and that the original publication in this journal is cited, in accordance with accepted academic practice. No use, distribution or reproduction is permitted which does not comply with these terms. 